\title{
Os retratos de Maria Isabel e Maria Francisca de Bragança, de Nicolas-Antoine Taunay
}

\begin{abstract}
Elaine Dias $^{1}$
RESUMO: Nicolas-Antoine Taunay, pintor de paisagens francês, também realizou alguns retratos durante sua estadia na corte do Rio de Janeiro. Nessa cidade, em 1816 , ele pinta a rainha Carlota Joaquina e todas as suas filhas. Nesse conjunto, dois retratos sobressaem-se de modo especial: os hoje ainda inventariados como de Maria Francisca e de Maria Teresa, mas que provavelmente são o de Maria Isabel e o de Maria Francisca de Assis - princesas que, nesse ano, deixavam o Brasil para casar-se, respectivamente, com Fernando VII, o rei espanhol, e com seu irmão Carlos Isidro de Bourbon. Neste artigo, além de descrevermos os retratos (e analisarmos a questão da identidade das princesas retratadas), abordamos suas funções na sociedade das cortes e os principais artistas do gênero na Europa. Discutimos, também, as hipóteses que permeiam as escolhas de Taunay para sua execução. Nesse sentido, tratamos da possível circulação de tipologias entre ltália, Portugal, Espanha e França, buscando entender a forma como Taunay os realizou e as funções que doravante tais retratos ocupariam nas relações entre o Brasil e a Europa.

PALAVRAS-CHAVE: Retrato. Nicolas-Antoine Taunay. Maria Isabel de Bragança. Maria Francisca de Assis.

ABSTRACT: Nicolas-Antoine Taunay, French landscape painter, produced also several portraits during his stay at the Rio de Janeiro Court. In this city, in 1816 , he paints the queen Carlota Joaquina and all her daughters. In this group, two portraits have a very special way: the paintings still today catalogued as Maria Francisca and Maria Teresa, but probably being Maria Isabel and Maria Francisca de Assis - princesses that, in this year, left Brazil to marry the Spanish King Fernando VII, and his brother Carlos Maria Isidro de Bourbon. In this article, beyond to describe these portraits (and analyse the identities of the portrayed princesses), I analyse their functions in the Court society and the mains artists of this gender in Europe. I will discuss, as well, the hypothesis about the Taunay choices. In this sense, I will analyse the
\end{abstract}

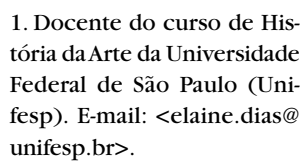

unifesp.br> 
2.A base de dados portuguesa Matriz Net apresenta as imagens e os inventários de todos estes retratos. Ver $<$ ht tp://www.matriznet.imc-ip. pt/MatrizNet/Home.aspx>

3. O casamento durou apenas dois anos, de 1816 a 1818, quando Maria Isabel morreu de parto (cesariana) em Madri.

4. O casamento durou de 1816 a 1834 possible circulation of the typologies of portrait between Italy, Portugal, Spain and France, understanding these productions by Taunay and the functions occupied by these portraits in the political relations between Brazil and Europe.

KEYWORDS: Portrait. Nicolas-Antoine Taunay. Maria Isabel de Bragança. Maria Francisca de Assis.

O conjunto de retratos da família Bragança que hoje se conserva no Palácio Nacional de Queluz é de grande interesse para a cultura brasileira e europeia do século XIX. Eles foram pintados por Nicolas-Antoine Taunay artista francês integrante da Missão Artística Francesa e residente no Rio de Janeiro entre 1816 e 1821 . São retratadas Carlota Joaquina e suas filhas Maria Teresa, Maria Isabel, Maria Francisca, Isabel Maria, Maria da Assunção e Ana de Jesus Maria, além de seu neto, filho do primeiro casamento de Maria Tereza, o pequeno Sebastião².

Em primeiro lugar, chama a nossa atenção a tipologia empregada em alguns dos retratos. A composição mais elaborada, o cuidado com a indumentária e com os acessórios conferem a dois deles uma particularidade que os aproxima de outros retratos europeus, sobretudo no que se refere a modelos específicos de retratística. Um outro elemento que levanta dúvidas - e que vai permear a discussão sobre os retratos - é a atribuição dos títulos aos quadros, sobretudo no que concerne à representação de duas princesas, Maria Isabel e Maria Francisca. Elas tiveram grande importância na política ibérica de alianças em 1816 e estreitaram os laços políficos e familiares entre Portugal, Brasil e Espanha, casandose, respectivamente, com Fernando VII, rei da Espanha ${ }^{3}$, e seu irmão Carlos Isidro 4 . Os noivos, que pertenciam à Casa dos Bourbon, eram irmãos de Carlota Joaquina e, portanto, tios das princesas portuguesas. Seguia-se, assim, a tradição luso-espanhola de casamento entre familiares.

Nesses retratos feitos por Taunay, tal evento, de suma importância, aparece representado no que consideramos miniaturas de Fernando VII e de Carlos Isidro, pintadas em camafeus portados pelas princesas, apontando para a relação política e afetiva com seus respectivos futuros maridos. A identificação conferida até agora aos retratos que portam essas miniaturas suscita-nos, porém, algumas dúvidas. No inventário da coleção do Palácio de Queluz, a descrição nos informa de que as retratadas - aí designadas como Maria Francisca de Assis e Maria Teresa -, trazem ambas miniaturas de Carlos Maria Isidro Bourbon nos camafeus pendurados ao pescoço. Isto poderia ser explicado pelo fato de terem as duas se casado com o mesmo Bourbon - primeiro Maria Francisca (1816) e, após a morte dessa em 1834, Maria Teresa lque já era viúva também de um Bourbon). A datação das obras, em seu conjunto, é atribuída ao ano de 1816. Nascem, assim, diversas dúvidas sobre as duas pinturas. Os retratos foram possivelmente produzidos ao mesmo tempo e, nesse ano, Maria Teresa ainda não havia se casado com o viúvo da irmã, Carlos Maria Isidro, fato vai ocorrer somente em 1838.

Os retratos foram possivelmente produzidos ao mesmo tempo e, nesta 
data, Maria Teresa ainda não havia se casado com o viúvo da irmã, Carlos Maria Isidro, fato que ocorrerá somente em 1838.

Neste caso, a princesa representada não seria Maria Teresa e, sim, Maria Francisca, que porta no peito o retrato do marido, com seu típico bigode e farda, conforme explicaremos mais adiante. $\bigcirc$ outro retrato - aquele considerado como sendo de Maria Francisca - seria, na realidade, de Maria Isabel, pois ela porta no peito a efígie não de Carlos, e sim do irmão dele, Fernando VII, dado que a miniatura é bastante semelhante a seus retratos produzidos no período.

A proposta deste artigo é promover o debate acerca da possibilidade de uma nova identificação e atribuição, explicando suas razões, e estabelecer uma estreita ligação com os modelos de retratística provavelmente utilizados pelo pintor na composição dos mesmos. A semelhança de composição, a realização de ambos no mesmo período, a importância do evento político do casamento, a tipologia específica dos dois retratos - além da semelhança das miniaturas com outros retratos de Fernando VII e Carlos Maria Isidro - são fatores que conduzem esta discussão.

Interessa-nos analisar os elementos artísticos, sociais e políiticos relativos a essas pinturas, além de suas referências pictóricas. $\bigcirc$ ambiente espanhol, nesse sentido, oferece rico aparato para um saboroso diálogo entre os retratos, possibilitando olhar de modo mais aguçado para a relação estabelecida não só entre as escolas francesa e portuguesa, mas principalmente as tradicionais retratísticas italiana, flamenga e espanhola, com as quais Taunay certamente mantinha contato. Analisaremos o papel do retrato e seus significados na Itália e na península lbérica, discutindo as relações entre os comanditários e os artistas, além da importância do retrato de Estado nessas cortes e aqueles realizados para apresentar os futuros noivos nos casamentos entre importantes famílias nobres europeias. Trataremos, nesta colcha de retalhos da pintura, da circulação de modelos para sua execução, do aparato iconográfico presente em cada uma das escolas artísticas, da importância primordial da política do período não só para as duas retratadas como também para a produção desse gênero pictural.

Para isso, é de suma importância a completa descrição e análise de características como a vestimenta, a pose, os acessórios e suas simbologias, assim como o atributo fundamental do retrato dentro do retrato, elemento de especial valor nessas composições, cuja relevância é de primeira ordem na história da pintura de corte. Analisamos a origem do modelo e sua circulação pela ltália e península lbérica, buscando entender os possíveis caminhos traçados por Taunay nesta trajetória entre o Brasil e a Europa.

Nicolas-Antoine Taunay: entre a França e o Rio de Janeiro

O retrato não era gênero estranho a Nicolas-Antoine Taunay, embora, na Europa, ele não fosse conhecido nem requisitado como pintor de retratos. É certo que, durante os séculos XVIII e XIX, o artista realizou paisagens pastoris, vistas

Annals of Museu Paulista. v. 19. n.1. July.-Dec. 2011. 
5.Sobre a trajetória de Nicolas-Antoine Taunay ver, sobretudo, Escragnolle Taunay, 1916, um de seus maiores biógrafos o completo e elaborado $\mathrm{ca}$ talogue raisonné do pintor escrito por Claudine Lebrun Jouve (Lebrun Jouve, 2003) e os recentes trabalhos de Lilia Schwarcz em O Sol do Brasil, além do catálogo da mostra destinada ao artista, em 2008 (Schwarcz com Dias, 2008), e Correa Do Lago, 2008.

6. Claude Joseph Vernet (1714-1789) era amigo pessoal de Nicolas-Antoine Taunay e foi um dos principais responsáveis por sua mudança na concepção da pintura de paisagem, sobretudo após a estadia em Roma. Entre tais transformações, o horizonte se torna mais amplo e alto; e os estudos de nuvens uma constante. Ver Claudine Lebrun-Jouve (2003)

7. Segundo Lebrun-Jouve,Taunay, no início de sua carreira, em razão do uso da cor nas cenas pastoris, aproxima-se diretamente da pintura de alguns artistas dos Países Baixos, entre eles Nicolaes Berchem (ou Berghem), um dos pintores estrangeiros mais apreciados em Paris no século XVIII. Taunay, no primeiro período de sua formação, fez uma cópia - que hoje se conserva no Musée des Beaux-Arts de Valence, França - de seu quadro Passage du gué.

8. Cf. Claudine Lebrun-Jouve (2003, p. 24), a viagem de Taunay à Suiça - moda no período - foi em 1779

9. Como pensionista da Académie de France, Taunay permaneceu em Roma entre 1784 e 1787 , protegido por Joseph-Marie Vien, membro da Academia Real de Pintura e Escultura. Cf. Claudine Lebrun-Jouve (2003, p. 37); ver também Lilia Schwarcz (2008). Aí, adquiriu os preceitos do classicismo e da nascente pintura neoclássica - com o estudo das ruínas, a nitidez do desenho, a aproximação à arquitetura geo- urbanas, cenas alegóricas, pinturas históricas e de batalhas ${ }^{5}$. Sua longa trajetória como pintor revela-nos um leque extraordinário de temas, de referências históricas e artísticas, de chaves interpretativas, cuja natureza se enriquecia nas mais diversas localidades e escolas artísticas que o formaram, na Itália e na França. Para sua produção pictórica, Taunay teve como referências a clássica França de Nicolas Poussin e Joseph Vernet ${ }^{b}$, a pastoril Holanda de Nicolaes Berghem 7 , a austeridade dos Alpes suíços ${ }^{8}$, o iluminado arcadismo da Cidade Eterna ${ }^{9}$ e, posteriormente, a exuberante e pouco conhecida paisagem carioca.

Em sua extensa produção, a pintura de retratos detinha um lugar mais íntimo e reservado, tendo como modelos distintos personagens próximos a ele. Retratou seus amigos pintores, como Hubert Robert e sua família ${ }^{10}$, Philippe-Auguste Hennequin 11, Gérard van Spaendonck'2, seu protetor Gabriel Godefroy ${ }^{13}$ e, principalmente, os membros de sua família. Nessa categoria, aparecem o próprio Taunay em curiosos autorretratos portando óculos de miopia; seu pai, PierreAntoine Henri Taunay ${ }^{14}$; sua sogra ${ }^{15}$, sua esposa Josephine ${ }^{16}$, e todos os seus filhos: Adrien-Aimé, Félix-Émile, Charles, Hypolithe e Théodore retratados em diferentes idades ${ }^{17}$. Além do interesse particular em mostrálos ao longo do tempo, desde a infância até a idade adulta, Taunay pinta com cuidado as vestimentas - desde as roupas infantis até a elegância da vida adulta ou o traje militar -, as suas feições em diferentes idades (como o adolescente bigode de Félix-Émile Taunayl, e sobretudo os atributos relacionados à educação artística e literária de seus filhos, incluindo nas composições livros, desenhos e pinturas. Como parte do seio íntimo da família, há o retrato da criada Jeanneton ${ }^{18}$ - onde o flerte com a tradição holandesa é bastante evidente.

Fora desse círculo, foram poucos os retratos produzidos. No Brasil, retratou alguns membros da corte luso-brasileira seguindo, possivelmente, objetivos bem concretos relacionados à sua estadia no Rio de Janeiro. Destacam-se aqui não somente os retratos de Carlota Joaquina e das princesas de Bragança, mas a paisagem histórica (tratada mais adiante) representando a mesma Carlota e D. João VI passando pela Quinta da Boa Vista. Além desses, também é conhecido o retrato de Dona Constança Manuel de Meneses, a marquesa de Belas, cuja composição com fundo neutro e vestimenta negra se aproxima dos retratos aqui estudados.

Neste artigo, os retratos que nos interessam são aqueles que consideramos ser de Maria Isabel (Figura 1) e de Maria Francisca (Figura 2)19, atualmente identificados como, respectivamente, de Maria Francisca e de Maria Teresa.

Tais retratos, que parecem ter sido compostos em conjunto, suscitam algumas dúvidas intrínsecas à encomenda deste gênero, tão especial para a realeza e tão pouco frequente para o pintor. Por que teria Taunay realizado essas pinturas? Encomenda de Carlota Joaquina ou um presente para ela? Teria o pintor realizado sessões de poses com os retratados ou baseado-se em gravuras? Ou seria um exercício de memória? Eles se restringem ao Brasil e Portugal ou se estendem à Espanha?

Nesse sentido, é conveniente destacar que Taunay - recém-chegado ao Brasil com seus colegas franceses para participar do projeto de uma Escola de Ciências, Artes e Ofícios, organizado por Joachim Le Breton e oferecido à 


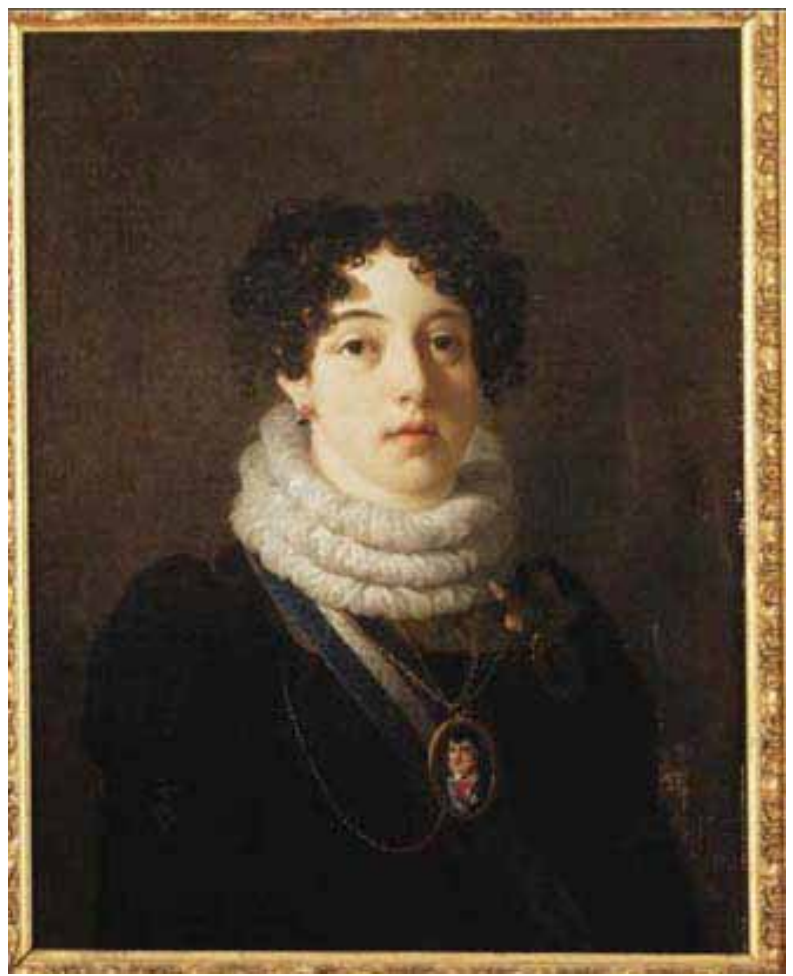

Figura 2 - Nicolas-Antoine Taunay. Retrato de Maria Teresa, 1816, óleo sobre tela, $64 \times 58 \mathrm{~cm}$. Palácio Nacional de Queluz, Queluz. Número de inventário: DDF 00106/TC, autor: Paulo Cintra / Laura Castro Caldas, 1990, localização: DDF-IMC. A pintura é atribuída neste artigo como Retrato de Maria Francisca.
Figura 1 - Nicolas-Antoine Taunay. Retrato de Maria Francisca, 1816, óleo sobre tela, $64 \times 58 \mathrm{~cm}$. Palácio Nacional de Queluz, Queluz. Número de inventário: DDF 001 15/TC, autor: Paulo Cintra / Laura Castro Caldas, 1990, localização: DDF - IMC. A pintura é atribuída neste artigo como Retrato de Maria Isabel.



Annals of Museu Paulista. v. 19. n.1. July.-Dec. 2011. 
metrizada e racional -,além das lições de Jacques-Louis David, que na época também estava em Roma.

10. Hoje desaparecido, o retrato Hubert Robert et sa famille é uma miniatura datada dos anos 1778-1780. Cf. Claudine Lebrun-Jouve (2003, p. 121). Foi um dos primeiros retratos realizados por Taunay.

11. Philippe-Auguste Hennequin (1762-1833), pintor de história, de retrato e desenhista. Seu retrato feito por Taunay (intitulado $\mathrm{Ho}$ mem com brinco) está em Paris, em coleção particular. Cf. Claudine Lebrun-Jouve (2003, p. 185-186).

12. Gérard van Spaendonck (1746-1822), pintor de flores. $O$ retrato que Taunay fez dele está conservado no Musée National du Château, em Versailles. Cf. Claudine Lebrun-Jouve (2003, p. 274).

13. Um de seus retratos está hoje em coleção particular, em Paris. Cf. Claudine Lebrun-Jouve (2003, p. 200-201).

14. Esse retrato em miniatura está conservado no Museu Paullista da Universidade de São Paulo. Cf. Claudine Lebrun-Jouve (2003, p. 124).

15. O retrato de Catherine-Rose Caron, sua sogra, está desaparecido. Cf. Claudine Lebrun-Jouve (2003, p. 177)

16. Entre seus retratos mais conhecidos estão um desenho (conservado em coleção particular, em São Paulo) e uma pintura (em coleção particular, em Paris). Cf. Claudine Lebrun-Jouve (2003, p. 199).

17. Dos retratos de seus filhos, a maioria está conservada no Museu Nacional de Belas Artes, no Rio de Janeiro. Ver Schwarcz com Dias (2008).

18. O retrato da criada Jeanneton está no Museu Nacio- corte portuguesa ainda em Paris ${ }^{20}$ - depara-se com um ambiente social e artístico distinto do francês. Ademais, suas relações com seus compatriotas artistas não são das mais cordiais ${ }^{21}$. Sem a possibilidade imediata de encomendas públicas e privadas, Taunay espera obter no Brasil, sobretudo junto a Dona Carlota Joaquina, um lugar de destaque na corte, disputando com seus colegas as ínfimas chances de produção artística. Em seu trabalho, recuperando documentação a esse respeito, Lilia Schwarcz já destacou o quanto Taunay se aproxima de Carlota, seja para cuidar da coleção real ou para ser professor de desenho das princesas. A paisagem histórica da Quinta da Boa Vista e os retratos realizados no período podem ser um indício de tal ligação, seja por encomenda ou por oferecimento. Na tela D. João e D. Carlota Joaquina passando a Quinta da Boa Vista perto do Palácio de São Cristóvão, hoje conservada no Museu Nacional do Rio de Janeiro, rei e rainha passeiam pela paisagem carioca assistidos por alguns de seus súditos e pelo próprio Taunay, que, em atitude de respeito, curva-se para os reis. A tela pode ser mais um indício do interesse do artista em fazer parte daquela corte. Claudine Lebrun-Jouve, autora do Catalogue raisonné do artista, também não confirma se o quadro foi encomendado pelos reis ou a eles oferecido: "A-t-il fait un hommage du tableau au roi, espérant obtenir sa protection? II était nécessaire de 'faire sa cour' à Rio"22, como ela nos relata.

É nesta corrente do "faire sa cour" que inserimos os retratos de Maria Isabel e Maria Francisca. Antes, porém, é necessário expor as funções intrínsecas ao retrato - esse poderoso gênero da pintura -, tratando de suas principais características, sobretudo no ambiente de corte europeu.

\section{Funções e significados da retratística na Europa}

Verossimilhança, beleza, poder, exemplo, alma, memória. Esses são alguns dos conceitos que podem ser reconhecidos na tradição da pintura de retratos. Podem ser visualizados e sentidos em sua contemplação e recepção, elucidados e confirmados pela imagem e pela teoria ao longo dos séculos. É notória a anedota contada por Cícero sobre Zeuxis, pintor clássico do século V a.C. que teria pintado, em Crótona, o retrato de uma mulher idealmente bela a partir das partes de outras cinco jovens e dos relatos de Homero sobre Helena, criando a imagem de uma figura feminina de beleza incontestável, exemplar e não menos ilusória ${ }^{23}$. Séculos depois, em De Pictura ${ }^{24}$, Leon Battista Alberti abordará a importância do retrato no Renascimento, analisando os elementos relativos à imitação, à memória e à verossimilhança: "assim a fisionomia de quem já está morto vive pela pintura longa vida"25. E neste "prolongamento", nota-se, nas Vidas, de Giorgio Vasari26, a importância do atributo ou dos emblemas, dos signos ou objetos presentes no retrato, da paisagem representada, pois nos possibilitam a compreensão da biografia do retratado e de suas ações no passado ou no presente, reforçando suas próprias virtudes.

$\bigcirc$ retrato será o representante visual da história daquele indivíduo e da 
sociedade onde vive, revelando sua vida - seja gloriosa e imitável, seja contestável ou passível de ser "apagada" 27 -, além de poderoso transmissor da cultura e dos hábitos de uma época. Assim, as noções que explicam o desenvolvimento da pintura do retrato ao longo dos séculos encontram terreno fértil até o século XIX. Na França do século XVII, por exemplo, o retrato porta valores relacionados ao sagrado, ao ensinamento e à moral, superiores até mesmo à imitação do modelo real$^{28}$. Mas será sobretudo pela representação da realeza que a pintura de retratos encontrará um valor de grande monta, principalmente com imagem do rei Luís XIV, por meio de um jogo real e ideal promovido por um conjunto de atributos, conduzindo a adoração de toda uma legião de súditos, sobretudo pelos pincéis de Hyacinthe Rigaud ${ }^{29}$.

retrato cumpre a função, entre outras, de reforçar um novo estatuto de poder e reafirmar a figura representada em sua condição política, ampliando seus valores morais condicionados às famílias e ao poder que vão servir de exemplo aos demais. Tornavam-se, assim, dignos de imitação. Acabamos de mencionar essa questão quando tratamos do retrato de Luís XIV, adorado pelos franceses. $\bigcirc$ chamado retrato de Estado ${ }^{30}$ tem lugar de destaque nesta função, onde as características públicas e os símbolos do retratado em sua função política assumem grandes significados, muitas vezes relacionados a virtudes do mundo antigo. Essa fórmula encontra terreno fértil ainda no Renascimento, com pintores como Rafael e Tiziano, sendo este último, por sua atuação como pintor na corte de Carlos V, um artista importante tanto no ambiente italiano quanto no espanhol. Há, no caso de Tiziano, um fator de grande importância para a retratística italiana, em um momento onde cada vez mais o retratado se despersonalizava, em prol dos atributos que the conferiam valor. $\bigcirc$ artista veneziano não dispensa os atributos, sobretudo em terreno italiano, mas vai incorporá-los de maneira mais "sóbria", dando singular importância ao retratado, levando a ele, à sua persona, uma força interna e poderosa. Como ressalta Castelnuovo:

Com os retratos do duque de Mântua, do duque de Ferrara, do duque de Urbino, com os de Carlos V, de Felipe II, do papa Paulo III, Ticiano oferece soberbos modelos ao retrato de corte. Não sendo originário de uma sociedade nem de uma cultura cortesãs, ele poderá fazer uma aposta surpreendente: rodear seu personagem de uma aura simbólica, sobriamente evocada por atributos, instrumentos e objetos cheios de alusões, apresentando-o de modo que sua imagem ocupe inteiramente o campo dos significados alegóricos e supraindividuais que se quer atribuir-the, mas de maneira que ela não apareça despersonalizada e possa ser lida ao mesmo tempo como metáfora e história ${ }^{31}$.

Nos séculos XVI e XVII, período em que o retrato tem ampla difusão na Europa, notamos como esses valores se exprimem através dos reis e sua corte, da nobreza, do clero e dos homens ilustres que figuram nas paredes das grandes famílias. Há relato, por exemplo, da existência de retratos de Cristóvão Colombo, Ariosto e Cícero nos aposentos de Felipe II, no Alcazar del Escorial, como símbolos de valores morais a serem emulados pelo rei ${ }^{32}$.

A esse respeito, em seu Dialogos de la pintura, publicado em 1633, nal de Belas Artes, no Rio de Janeiro.

19. Antes considerados de autoria anônima, foram atribuidos a Taunay por Claudine Lebrun-Jouve (2003), no catalogue raisonné. Além dos retratos das princesas, também foram atribuídos a Taunay aqueles da rainha Carlota Joaquina, das princesas Maria Teresa, Isabel Maria, Maria da Assunção, Ana de Jesus Maria, e de Sebastião Gabriel - filho de Maria Teresa com seu primeiro marido, o infante Don Pedro Carlos de Espanha.

20. Sobre todos os acontecimentos que permearam a vinda dos franceses ao Brasil em 1816 e, ainda em Paris, a origem do projeto de Joachim Le Breton junto à corte portuguesa, ver Mário Pedrosa (1995); Affonso d'Escragnolle Taunay (1957); Lilia Schwarcz (2008); e Elaine Dias (2005a; 2005b; 2006; 2009).

21 . Em carta de 1816 , Jean-Baptiste Debret relata a um amigo francês as animosidades - entre ele, Joachim Le Breton e Nicolas-Antoine Taunay - na disputa por um lugar de destaque na corte dos Bragança. A carta está conservada na Bibliothèque de l'Institut National d'Histoire de l'Art, Collections Jacques Doucet, em Paris. Ver Elaine Dias (2005b); e, também, Claudine Lebrun-Jouve (2003).

22. Cf. Claudine LebrunJouve (2003, p. 288).

23. Ver Cicero (1840); e Édouard Pommier (1998, p. 50).

24.Ver Leon B.Alberti (1996).

25. Idem, v. 2, p. 101.

26.Ver Giorgio Vasari (2001).

27. Poderiamos citar aqui a damnatio memoriae, isto é, a condenação ou o apagar da memória. É a prática, 
proveniente da Roma Antiga, de anularem-se as honras de alguns políticos, apagando seu nome das inscrições, ou destruindo imagens de sua face e as estátuas que o representam, como aconteceu, por exemplo, com Calígula. Ver Eric R.Varner (2004).

28. André Félibien (16861688) e Charles Perrault (1667) discutem a questão da retratística de Luís XIV. Os franceses terão como referência segura a teoria e a produção italiana do $\mathrm{Re}$ nascimento e também de artistas do norte da Europa como Holbein e Van Dyck, entre outros. Roger de Piles em sua obra Abregé de la vie des peintres, também relata suas preferências nesse âmbito, onde novamente Holbein e Van Dyck figuram em lugar de excelência ao lado de Tiziano, entre outros artistas. Em sua obra, de Piles também discute as questões econômicas em torno do retrato, como os ganhos do artista na profissão. Além disso, será uma referência importante aos enciclopedistas e ao teórico alemão Johann Georg Sulzer na discussão sobre o retrato. Ver Édouard Pommier (1998).

29. Ver Peter Burke (1994).

30. Cf. Enrico Castelnuovo (2006, p. 54).

31. Idem, p. 56.

32. Cf. Miguel Falomir Faus (1999, p. 207).

33. Cf. Édouard Pommier (1998, p. 287)

34. Vicente Carducho, apud Alfonso Pérez Sánchez (2004, p. 199). A publicação de Vicente Carducho - que considerava a Espanha a sua pátria, mesmo sendo eterno partidário da pintura italiana - é considerada a primeira grande obra teórica espanhola.Cf.. Édouard Pommier, (1998, p. 287).
Vicente Carducho - que vivera na Espanha no mesmo período em que Federico Zuccari, um dos principais artistas do Escorial $^{33}$ - comenta sobre o retrato:

Cosa pía es, y más quando les mueve el amor lícito de los padres, hermanos, parientes o amigos; y tanto más quanto fueren de personas santas, y virtuosas; para dar motivos a la imitación de aquellas virtudes de que fueran adornados [...] Después, como escrive Lactancio, sólo a los Reys y Príncipes fue permitido al retratarse, quando huviesen hechos cosas grandes, y governado bien, sirviendo esto de cierto premio honroso a su mucho valor, animando con esto a los que sucediesen al gobierno para que a su imitación procediesen con bondad y con justicia ${ }^{34}$.

Há, nesse sentido, um caráter fortemente educativo, uma vez que o retrato imediatamente se converte em exemplo moral a ser admirado e, portanto, emulado. No caso da península lbérica, lugar de destino de Maria Isabel e Maria Francisca, a tradição do retrato veio acompanhada de um vasto interesse por galerias de pinturas desse gênero específico e de publicações em que havia gravuras desses retratos. Temos, neste caso, o Libro de descripción de verdaderos retratos de ilustres y memorables varones, obra de Francisco Pacheco, de 1599, e a série de gravuras Retratos de los españoles ilustres, editada entre 1788 e 1814 , para citarmos alguns dos trabalhos espanhóis anteriores à realização das telas de Taunay. Mas, ainda antes desses, no século XVI, cabe ressaltar a importância de Francisco de Holanda, um dos primeiros retratistas da corte de Juana de Áustria, em Lisboa, e suas pinturas neste gênero realizadas a partir de 1541, momento em que regressava de Roma. Esse artista, que junto com seu pai Antonio de Holanda gozava de especial prestígio, passou pela ltália e esteve presente também na Espanha, aproximando-se da corte de Carlos V e Isabel de Portugal. Era um admirador da arte flamenga e do excepcional realismo das pinturas dessa escola, dos minuciosos detalhes que faziam do retrato um gênero repleto de significações e era, igualmente, um amante da obra de Tiziano. Não só Holanda como os demais estudiosos e artistas do Renascimento reconheceram esta grandeza da escola veneziana centrada em Tiziano, iniciando-se então um novo olhar para o gênero do retrato, incorporando as características dessas importantes escolas artísticas.

Francisco de Holanda não se limitou a pintar retratos de corte, mas elaborou, também, em 1549, a obra Do tirar polo natural, que alguns consideram o primeiro tratado consagrado inteiramente à arte do retrato. Aí, entre várias considerações, consta que só reis, príncipes ou pessoas de grande mérito devem ser retratados; que a composição deve ser em três quartos, com a figura iluminada frontalmente; e que, se o retrato for realmente bom, a personagem deve ser reconhecida pela orelha. Também aconselha, à maneira de Alberti e a exemplo de Apeles, minimizar os defeitos físicos. Embora não tenha sido publicada no período (mesmo havendo uma versão que circulava em espanhol), a obra tornouse conhecida na prática por meio das pinturas do flamengo Antonio Moro e de seu discípulo Alonso Sánchez Coello, principais expoentes da retratística espanhola.

Além da importância dessas publicações - e embora conservassem 
características importantes da retratística de Flandres e do modelo do norte da Europa $^{35}$ - , esses artistas terminaram por ampliar sua formação para a execução do retrato de corte, aproximando-se de Tiziano. Sabemos o quanto este último foi um artista importante no âmbito do retrato, dando ao gênero um caminho diferenciado na escola flamenga, reforçando a personalidade das figuras na composição ${ }^{36}$. A península lbérica pôde usufruir das duas escolas, não só devido à formação de seus artistas em Flandres, mas também pela presença das obras de Tiziano na corte de Carlos V, embora este optasse, ao fim e ao cabo, pelo austero modelo germânico ${ }^{37}$. Nesse sentido, Jonathan Brown ressalta que Carlos $\checkmark$ mantinha sua preferência por um retrato com poucos atributos e mais austero, e termina por impor tal vontade a Tiziano. Este pintor, com sua excelência, incorpora a faceta enérgica e absolutamente grandiosa do Imperador $^{38}$ a essas características.

A retratística assumirá, assim, características importantes, sobretudo no período do Renascimento. Além da Itália, também a Espanha será um centro influente no desenvolvimento do gênero, não só chamando para seu território artistas flamengos e italianos, mas também fazendo com que seus artistas se formassem no seio dessas escolas artísticas, renovassem suas características e criassem um modelo próprio. E o século XVII será um dos períodos mais férteis para o florescimento da retratística na Espanha. A época de Felipe II, filho de Carlos V, vai ser aquela a incorporar, ao retrato, características de suma importância para a representação da Realeza, assumindo grande valor, força dramática e simplicidade, a partir da inserção de poucos elementos. Este modelo irá se tornar "esquema canônico para seus sucessores", ao menos até o século XVIII, como bem ressalta Jonathan Brown ${ }^{39}$.

A Espanha foi, por excelência, o país onde o retrato cumpriu uma função de grande importância na realização de casamentos por aliança política. Consta que Fernando VII e Carlos Isidro podem ter recebido os retratos em miniatura das princesas de Bragança antes da realização do casamento ${ }^{40}$, e é totalmente provável que a atitude tenha sido recíproca. N oivos que nunca se viram encetavam, através desse objeto, a primeira apresentação, que então se convertia em relação afetiva ou, na pior das hipóteses, em sentimento de repulsa, sobretudo após contemplar um retrato de características mais realistas e não desejáveis. Nesse caso, restava conformar-se com a situação e preparar-se para o primeiro encontro físico com os retratados e suas características já antecipadas pelo retrato. No Brasil, D. Pedro II recebeu, diretamente de Nápoles, belos retratos da imperatriz Teresa Cristina, como nos relata Lilia Schwarcz:

Contam os relatos que o monarca, apesar de sua habitual moderação, afirmou ter gostado da imagem, que na verdade realçava apenas as qualidades físicas da futura Imperatriz. No primeiro retrato aparecia uma jovem com belo penteado, um leve sorriso e cachinhos emoldurando um rosto gorducho. Atrás, o Vesúvio, prova da origem da futura esposa [...]. No entanto, malgrado as informações que the haviam chegado sobre as virtudes da imperatriz, D. Pedro só pôde notar-the os defeitos: Teresa Cristina era baixa, gorda, e além de tudo coxa e feia. A decepção estampou-se no resto do jovem monarca, que, dizem, chorou nos braços da condessa de Belmonte, a Dadama, sua aia ${ }^{41}$.
35. Cf. Jonathan Brown (2001, p. 48). Ver também Lorne Campbell (1990).

36. É importante ressaltar que, em Veneza, Giorgione, mestre de Tiziano, desenvolve plenamente essa característica, incutindo em seus personagens o caráter psicológico, a "sua condição existencial". Nisso,Tiziano segue o mestre, mas incorpora ao retrato outros elementos além de tal caráter. Cf. Enrico Castelnuovo (2006, p.61).

37. Cf. Jonathan Brown (2004, p. 130).

38. Ibidem.

39. Idem, p. 132.

40."A escolha das noivas, provavelmente feita através de informações escritas e ainda por intermédio de retratos-miniaturas, foi, depois de vencidas todas as dificuldades, comunicada ao Príncipe Regente em carta reservadíssima (30-III-1815)". Cf. Angelo Pereira (1946, p. 176).

41. Cf. Lilia Schwarcz (1998, p. 93-95). 
42. Cf. Martin Warnke (2001, p. 301-317).

43. Miguel Falomir destaca o decorum como a "adequada representação da ideia de majestade". Cf. Miguel Falomir Faus (1999, p. 210).

44. Alberti está se referindo a Apeles, que escondeu os defeitos físicos do rei em seu retrato.

45. Cf. Leon B.Alberti (1996, p. 121).

46. Cf. Martin Warnke (2001, p. 315).

47. Lorne Campbell destaca, ainda, que o retrato - de frente - realizado por Holbein disfarçava o grande nariz de Ana de Clèves. O artífício da pose foi usado para amenizar o defeito da noiva. Cf. Lorne Campbell (1990, p. 85).
Fora, então, D. Pedro enganado por um retrato idealizado? Certamente a pintura não era fiel às características físicas da princesa, o que colaborou para confirmação do contrato de casamento. E D. Pedro II não foi o único. Também Felipe II teve o mesmo descontentamento ao ser "enganado" pelo retrato de Maria Tudor, que não tinha a mesma beleza da pintura que fora apresentada a ele. Os retratos reais deviam seguir regras que limitavam, em muito, a noção de realismo. Nesse sentido, Martin Warnke ${ }^{42}$ destaca o quanto a questão da imitatio - isto é, a verossimilhança, associada ao decorum ${ }^{43}$ - ligava-se ainda a outro fator de extrema importância na realização de retratos para essas funções diplomáticas, sobretudo de reis: a dissimulatio. Tais relações apareciam já na Antiguidade. Abordada por Plinio, o Jovem, em sua História Natural e por Quintiliano em Instituições Oratórias, tal ideia é retomada por Alberti em De Pictura:

Os antigos pintavam o retrato de Antigono ${ }^{44}$ somente exibindo a parte da face em que não havia falta do olho. Dizem que a cabeça de Péricles era comprida e feia; por isso, ao contrário das outras pessoas que apareciam com a cabeça descoberta, foi retratado por pintores e escultores com elmo. Diz Plutarco que os pintores antigos, quanto pintavam os reis, se neles houvesse algum defeito que não queriam que passasse despercebido, corrigiam-no na medida do possível, mantendo embora semelhança ${ }^{45}$.

A esse respeito, o historiador Miguel Falomir destaca que tal dissimulatio não pretendia falsear a realidade, mas, sim, potencializar os aspectos morais do retratado, minimizando seus defeitos. $\bigcirc$ mesmo se passava com os retratos femininos. A obviedade de uma recusa do retrato realista era certamente deixada de lado, em prol de um retrato idealizado e belo. Felipe II, D. Pedro II, e suas respectivas esposas foram personagens dessa ilusão. Houve, no entanto, tentativas de reverter a situação. Para sanar o problema, eram enviados, junto ao pedido oficial, documentos e mensageiros rogando que nos retratos fosse representada a aparência mais fiel possível à do modelo, ou tomavam atitudes enérgicas em relação à escolha do artista. Por essa razão, para a realização do retrato da pretendente Ana de Clèves, Henrique VIII enviou seus próprios pintores, tentando evitar, assim, uma decepção posterior ao encontrar-se com a noiva. Seu pintor, no entanto, não realizou o retrato, pois Holbein, o Jovem, estava já a caminho da corte para realizá-lo46. A decepção de Henrique VIII deve ter sido grande ao ver que Holbein cobrira as marcas de varíola e a feiura da princesa, embora não se esperasse outra atitude desse consagrado pintor. Dentro das condições do decorum do retrato de corte, não havia sentido ser realista. Porém, o impacto e a ilusão poderiam ter sido evitados se o pintor de sua confiança tivesse, de fato, realizado a pintura. Henrique VIII casou-se a contragosto com Ana de Clèves, e o casamento (não consumado) foi anulado passados seis meses ${ }^{47}$.

Também não podemos deixar de notar o célebre caso dos retratos de Margarita Teresa, filha de Felipe IV, feitos por Diego Velázquez para o noivo desta, o rei Leopoldo I, da Áustria. Entre eles estão os retratos hoje conservados no Kunsthistorisches Museum, em Viena - destacando-se o Retrato da infanta Margarita con vestido azul -, que mostram a retratada em diferentes idades, para 
que o rei pudesse acompanhar seu crescimento. Ao que parece, Leopoldo I não apreciava tanto os retratos feitos pelos espanhóis, sobretudo aquele da Infanta em azul48, de Velázquez, encarregando Gerard van Schloss (também conhecido como Gérard Duchâteau), pintor de sua corte, de realizar o retrato oficial da noiva (também conservado no Kunsthistorisches de Viena) ${ }^{49}$. À escola sevilhana de Velázquez, Leopoldo I preferia a flamenga, percebendo-se aqui, possivelmente, um contragosto a respeito do estilo do pintor e de sua notável solidez na construção escultural, com certa austeridade, da figura na composição, do que propriamente da beleza da retratada.

De outra parte, no reino espanhol, a repulsa ao retrato - em uma espécie de transferência sentimental do receptor ao objeto material, isto é, ao retratado, como se ele ali estivesse de fato - assumiu também formas quase anedóticas já no convívio do casal, como no caso de Maria Tudor e Felipe II:

Así, Maria Tudor, presa de un ataque de celos, arañó el retrato de Felipe [II], y, en otra ocasión, al saber que su esposo estaría ausente una larga temporada, retiró el retrato de su cámara, según alguns fuentes, sacándolo a puntapiés ${ }^{50}$.

Não foi o mesmo que se passou, no entanto, com Juana de Áustria, em negociações de seu casamento com João de Portugal. Após o intercâmbio de retratos, consta que Juana de Áustria teria adorado aquele realizado por Antonio Moro ${ }^{51}$ e Alonso Sánchez Coello ${ }^{52}$, mantendo com ele, antes do encontro com o amado, uma relação de afeto e até mesmo praticando a conversação. A mesma Juana, já na corte de Lisboa, também rejeitava o retrato nos momentos de ausência de seu marido 53 .

Nesse mesmo sentido - isto é, troca de retratos entre o casal e sua adoração por parte dos retratados -, Martin Warnke ressalta que isso ocorreu com um dos quadros do ciclo executado por Rubens a mando de Maria de Médicis (hoje conservados no Museu do Louvre). Antes do casamento, Henrique IV recebeu o retrato de Maria pintado por Frans Pourbus, o Jovem ${ }^{54}$. A cena foi pintada por Rubens anos depois da morte de Henrique IV e a presença dos cupidos carregando o retrato em direção ao rei demonstra a enorme satisfação, a surpresa, a paixão e o prazer em tê-lo recebido.

Para a realização deste gênero, isto é, o retrato, há elementos de fundamental importância. Semelhança, poses, penteados, vestuário, acessórios, escolha de fundos e cores fazem parte de uma composição estratégica. Todas as peças contribuem para a apresentação, a confirmação, a exaltação e a transmissão de uma ideia por meio de uma forma simbólica ${ }^{55}$. Todos os aparatos procuram transmitir os valores do retratado, de modo não somente a preservar sua memória mas igualmente com o intuito de educar aqueles que o contemplam, que o prestigiam, que aprendem com os retratados e seu papel no mundo.

A solução de figurar um retrato dentro do retrato é uma delas, e reaparecerá nas pinturas das princesas realizadas por Taunay no Brasil. Sua origem, entretanto, está na Itália, sendo retomada na corte dos Felipes.

André Chastel, um dos historiadores a aproximar-se deste tema, discute
48. Este foi o último retrato enviado por Velazquez ao rei Leopoldo I. Cf. Javier Portus (2004a, p.333).

49. "Con esta ocasión envío también allá mi ayuda de cámara Gerarden von Schloss, en galo du Chatto. Éste es bruselés, por lo tanto vasallo del rey y un hombre que merece todo. Educado de manera honrada, es pío y pinta muy bien, especialmente los retratos pequeños, como el que les envié hace un año. Por lo tanto es mi intención y mi voluntad, que le introduzcáis al lado de Harrach, así que reciba el permiso para retratar a mi esposa y al príncipe. Opus laudabit magistrum. Ha realizado mi retrato en grande y pequeño, los cuales lleva Harrach allá. Esto es mi alta voluntad porque los pintores españoles no me ofrecen ninguna satisfacción." Cf. Friedrich Polleross (2003, p. 151).

50. Cf. Miguel Falomir Faus (1999, p. 206).

51. Anthonis Moor Van Dashorst (Ultrecht, 1517 . Anvers, 1576), pintor holandês, conhecido na península ibérica como Antonio Moro, produziu retratos nas cortes de Portugal e Espanha. Ver Enrica G. Piscicelli et al. (1991).

52. Alonso Sánchez Coello (Alqueira Blanca, 1531 - Madrid, 1588), pintor espanhol, discípulo de Antonio Moro e pintor da corte de Felipe II. Ver Enrica G. Piscicelli et al. (1991).

53. Ver Annemarie Jordan (1994).

54. Cf. Martin Warnke (2001, p. 313-314).

55. Cf. Peter Burke (2004, p. 31). 
56. Cf. André Chastel (2000, p. 80).

57.A obra pertence à Galleria degli Uffizi, em Florença.

58. Cf. Julian Gallego (1978, p. 78).

59. Cf. Ronald Lightbown (1978, p. 33-35).

60. Este retrato, realizado entre 1471 e 1474 , possivelmente foi o modelo para Botticelli. Está no Koninklijk Museum voor Shonen Kunsten [Museu Real de Belas Artes] da Antuérpia.

61. Em sua obra, Barbara Lane (2009, p. 205-207) discute as atribuições ao retratado.

62. Cf. Giorgio Faggin (1973, p. 258).

63. O retrato está conservado na Galleria degli Uffizi, em Florença. alguns dos elementos que fazem parte de tal concepção. É importante citarmos, neste caso, a importância do tema relativo a São Lucas pintando o retrato da Virgem. É estabelecida uma ligação entre o santo, que ocupa o lugar de pintor - portanto do artista em seu ofício, como "uma cena de gênero e uma alegoria" -, e a Virgem, evidenciando, como ressalta Chastel, "que a pintura tem a vocação do sagrado" 56 . Esta complexa questão do quadro real e do quadro ilusório dentro do quadro poderia ser exemplificada por outras pinturas, por exemplo, de artistas dos Países Baixos. Chastel relata que Vermeer, por exemplo, transforma o tema de São Lucas naquele do artista retratado pintando em seu ateliê. Outros exemplos vão surgir, principalmente durante o Renascimento, e é aqui que gostaríamos de ressaltar a questão que nos concerne de perto, isto é, o retrato dentro do retrato.

Tornou-se célebre o retrato, feito por Sandro Botticelli por volta de 1475, em que a figura de um homem segura de maneira veemente o medalhão com a efígie de Cosimo de Médici ${ }^{57}$. Essa pintura constituiu um exemplo marcante da composição do retrato dentro do retrato. No entanto, o diálogo entre imagens e gêneros já havia aparecido na pintura religiosa do século XV, com a representação de Verônica segurando o tecido com a imagem de Cristo em sangue e suor. Caracterizada e compreendida como um retrato, a dupla composição revelava a relação entre ambos, "a viva recordação de sua piedade" e a confirmação da hierarquia religiosa, eternizada por meio da imagem ${ }^{58}$. A tipologia foi, assim, transformada, e subtraída da esfera religiosa, passando para o âmbito social e humanístico, ligando o homem do Renascimento, por meio das medalhas, ao período antigo - fosse pela representação dos homens desse tempo no suporte antigo ou pela contemplação da virtude antiga. No caso de Botticelli, sabe-se a identidade do homem representado na medalha - Cosimo, o velho, contemporâneo ao pintor -, mas, após muitas discussões historiográficas, não se chegou a qualquer conclusão a respeito da figura central que a sustenta em posição frontal ${ }^{59}$. Trata-se, indiscutivelmente, de um retrato de homenagem, onde a medalha, de tamanho considerável e visível na composição, exibe sua grande importância para o personagem principal. $\bigcirc$ retrato na medalha dialoga diretamente com tal personagem, conferindo-the valor, não o contrário. $O$ mesmo acontece no Retrato de um homem com medalha, de Hans Memling 60 . A identidade do retratado é igualmente discutida pelos historiadores, variando de um medalhista a um colecionador de medalhas antigas, ou mesmo o humanista Bernardo Bembo, este último em razão das palmeiras na paisagem, símbolo presente no emblema de seu nome ${ }^{61}$. $\bigcirc$ homem segura na mão esquerda uma medalha de Nero, o que confere ao retratado principal, segundo nos relata Giorgio Faggin, não só a mesma motivação que apresentava o imperador romano pelas artes - relação usual entre os humanistas do Renascimento - mas também o interesse pela medalhística daquele período62. Trata-se de uma relação estabelecida entre a Antiguidade e o retratado no século XV, reforçando o caráter clássico e humanista da cultura renascentista.

Menos de um século depois, em seu Retrato de Biab3 (Figura 3), Bronzino colocava uma pequena medalha pendente sobre o rico vestido em seda 




64. Cf. Carlo Falciani e Antonio Natali (2010, p. 132).

65. Ibidem.

Figura 3 - Bronzino. Retrato de Bia d'Medici, 1542, têmpera sobre painel, $63 \times 48 \mathrm{~cm}$. Galleria degli Uffizi, Florença.

branca, que contrasta de forma espetacular com o fundo em lápis-lazúli. Não se trata de uma medalha antiga, mas de alguém relacionado à pequena Bia (seu pai, o duque Cosimo I de Médicis, grão-duque da Toscana), à semelhança do que fizera Botticelli anos antes com o fundador da dinastia dos Médici. A medalha inteiramente adornada exposta no peito da criança foi realizada, segundo os biógrafos do artista, a partir do retrato realizado por Pontormo anos antes $^{64}$, mantendo também uma estreita relação com a medalha de Cosimo I cunhada por Domenico di Polo de'Vetri em 1537. Neste caso, o pequeno retrato dentro do retrato denota a relação de parentesco e afeto entre os retratados, ainda que Bia fosse filha ilegítima de Cosimo antes de seu casamento com Eleonora de Toledo. Pode ainda ser uma homenagem do pai à filha, considerando a hipótese de Cosimo ter encomendado o retrato a Bronzino após a morte da criança, em $1542^{65}$.

Já no âmbito espanhol, é o aparato da medalha ou do camafeu que vai predominar na representação de Carlos V e Felipe II nos retratos de família. A primeira tela em que o objeto aparece como símbolo de correspondência entre a figura principal e a figura em miniatura é o Retrato de Juana de Áustria ou Joana de Portugal (Figura 4). Vestida de negro, ela carrega, seja no peito, seja nas mãos, ora a miniatura de seu irmão Felipe II, ora aquela de seu pai, Carlos V. A história política de Juana de Áustria liga-se diretamente à família dos Bragança e, portanto, às nossas princesas. 
Figura 4 - Alonso Sanchez Coello. Retrato de Dona Juana de Áustria, Princesa de Portugal, 1557, óleo sobre tela, $116 \times 93 \mathrm{~cm}$. Museo de Bellas Artes, Bilbao.

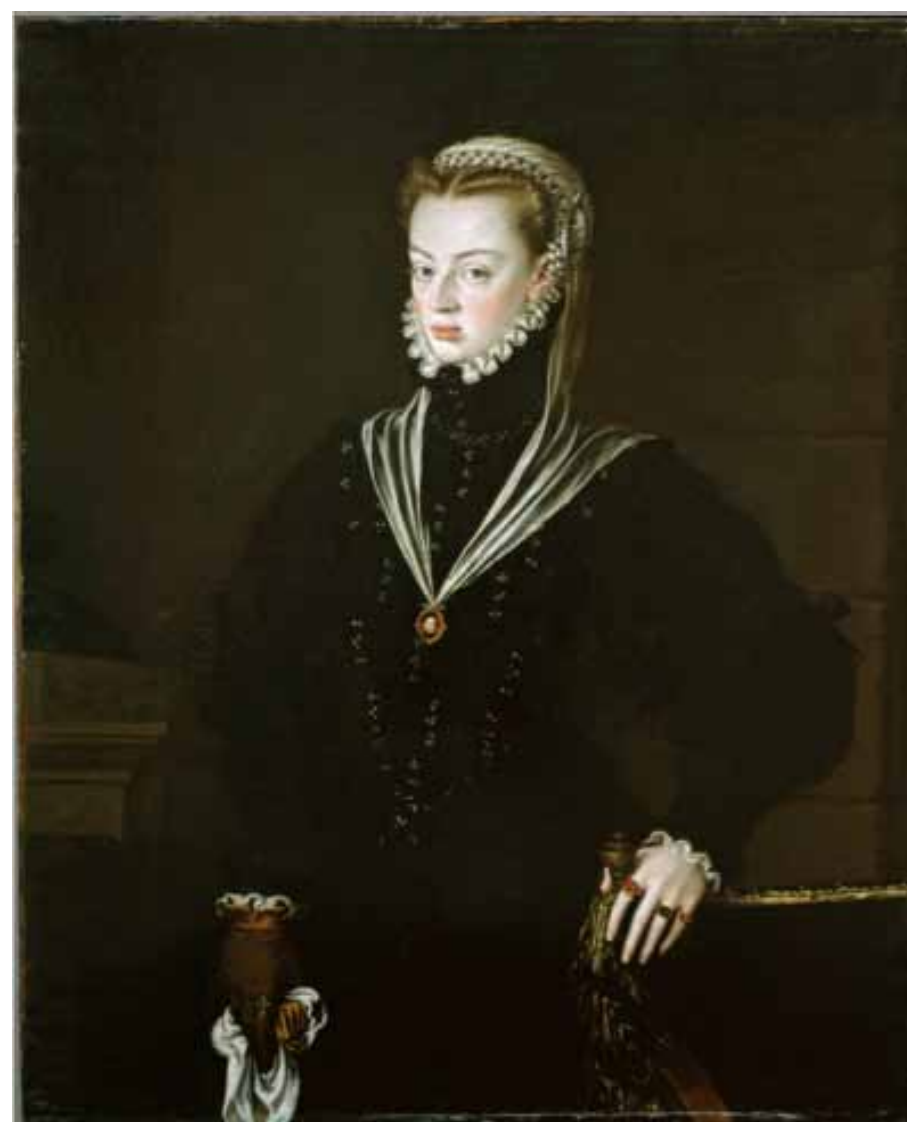

66. Cf. Juan Miguel Serrera (1990,p. 139).

67.A presença de uma criança neste retrato relaciona-se, possivelmente, à entrada de crianças na vida monacal do Convento de las Descalzas Reales de Madrid, instituição fundada por Joana. O retrato está conservado no Isabella Stewart Gardner Museum, em Boston. Cf. Fernando Checa Cremades (1999, p. 361)
Filha de Carlos V, Juana casa-se com João III de Portugal em 1553, partindo da Espanha para aquele país onde se tornaria viúva no ano seguinte. Retorna então à Espanha, deixando em Portugal seu único filho, recém-nascido, o futuro rei D. Sebastião. Não mais voltou àquele país, conhecendo o filho e seu crescimento por meio do poderoso instrumento do retrato. Entre 1554 e 1559 em nome de Carlos V, seu pai, que abdicava do trono, e também em nome do irmão, Felipe II, que partia para os Países Baixos para casar-se com Maria Tudor -, assumiu a regência na Espanha. Provém daí a necessidade da inclusão de miniaturas de seu pai e de seu irmão nos retratos de Juana. Alonso Sánchez Coello fará alguns deles, da época da Regência. Aquele conservado no Museo de Bellas Artes de Bilbao mostra Juana de negro, rosto belo e firme, com uma luva em uma das mãos, portando em seu peito, como um colar, o retrato em miniatura de Felipe II, que parece ter sido feito a partir daquele pintado por Antonio Moro ${ }^{66}$. $O$ uso da efígie como um colar denota a intimidade da joia que se aproxima de seu corpo, reforçando a afetividade familiar e a continuidade do poder político desta poderosa família. Podemos notar ainda a presença de camafeu com retrato alla antica de Carlos V, seu pai, em pintura cuja autoria é atribuída a Sofonisba Anguissola ${ }^{67}$, possivelmente realizada em 1561, após seu retiro para a vida monacal no Convento de las Descalzas Reales. Em sua escultura fúnebre, realizada 
por Pompeo Leoni em 1574 ${ }^{68}$, novamente aparece o colar esculpido, desta vez com a efígie de Felipe II, eternizando a ligação entre os Habsburgo e a importância definitiva dos irmãos para o reino da Espanha.

A tipologia vai repetir-se nos retratos de Isabel de Valois e Isabel Clara Eugênia, que igualmente mostrarão, por meio da miniatura, a relação de parentesco e subordinação, respectivamente, ao marido e ao pai Felipe II.

$\bigcirc$ célebre retrato pintado por Alonso Sánchez Coello, conservado no Museo Nacional del Prado (Figura 5), mostra a princesa Eugênia ricamente vestida, tendo a seu lado a criada Magdalena Ruiz e, ao fundo tendo ao fundo a clássica coluna que remete aos Habsburgo ${ }^{69}$. A mão esquerda de Isabel está levemente apoiada sobre a cabeça de Magdalena, que era muito próxima da família real por ter servido, primeiro, a D. Juana e, posteriormente, às princesas filhas de Felipe II. Sua presença no retrato mostra a gratidão da família real por ela, que serviu a eles até morrer. Na outra mão, Isabel segura, colada a seu corpo e no centro do retrato, a miniatura da efígie de Felipe II que, segundo o inventário do Museo del Prado, "reproduce el busto en alabastro de Pompeo Leoni"70. A presença da miniatura do rei denota, como ressalta Maria Kusche, não só a relação de afeto entre pai e filha, mas a possibilidade da filha de ocupar o trono após a morte do pai $^{71}$. Já a criada Magdalena, cujo olhar se volta para a miniatura do rei, carrega

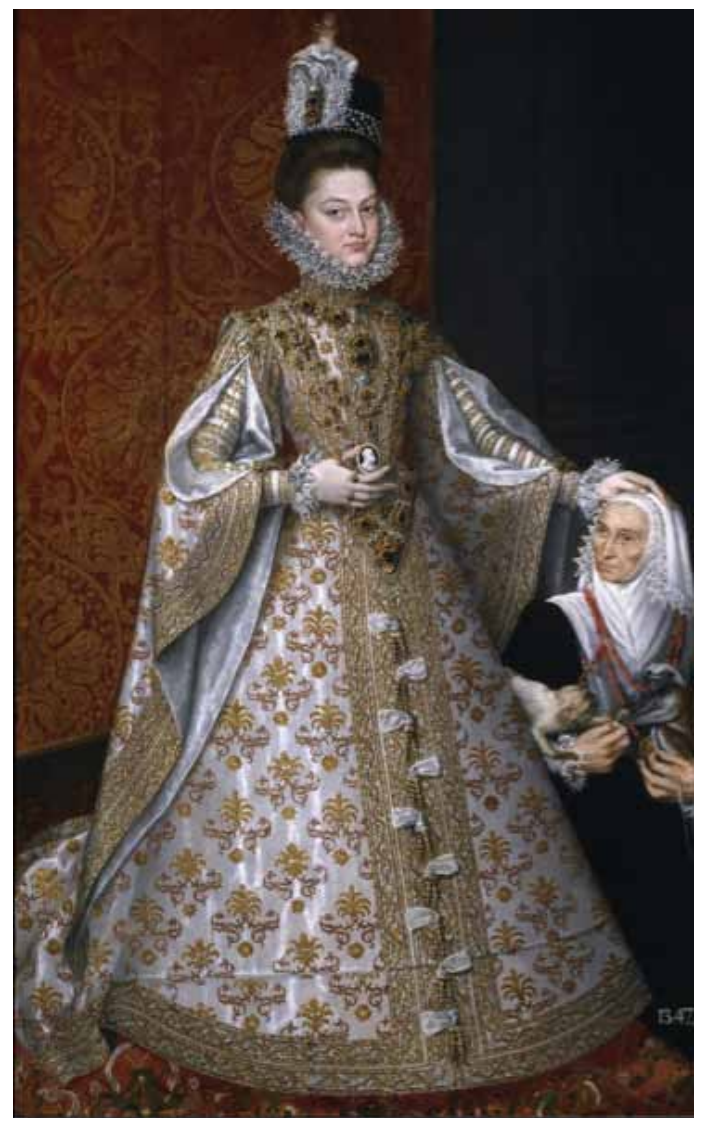

Figura 5 - Alonso Sanchez Coello. A Infanta Isabel Clara Eugenia e Magdalena Ruiz, 1585-1588, óleo sobre tela, $207 \times 129$ cm. Museo Nacional del Prado, Madri.
68. O corpo de Juana de Áustria está sepultado em Madrid, no Las Descalzas Reales, e não no Monastério del Escorial, onde sepultam-se os reis e rainhas espanhóis. A respeito da capela funerária feita por Pompeo Leoni, ver Javier Ortega Vidal (1998, p 40-54).

69. A coluna reaparecerá em outros retratos da corte de Carlos V e Felipe II e também em gravuras.

70. Número de catálogo: P00861 (La infanta Isabel Clara Eugenia y Magdalena Ruiz). A descrição presente no Prado sugere ainda como referência: "Por un lado, Isabel Clara Eugenia viste siguiendo los colores del vistoso ceremonial luso: oro sobre blanco, y Magadalena Ruiz, que en 1581 había acompañado a Felipe II a Portugal,lleva sobre el pecho lo que se ha interpretado como recuerdo de ese viaje, un collar de coral de dos vueltas. Además, entre las manos sostiene dos pequeños monos, ejemplares oriundos de la América amazónica”. Cf., também, Miguel Falomir Faus (1999, p. 404).

71. Cf. Javier Portús (2000, p. 201). 
72. Cf. Maria Kusche (2003, p. 441-443).

73.A tela do Museo Nacional del Prado fora antes atribuída a Alonso Sánchez Coello e Juan Pantoja de la Cruz. Ver inventário do Prado, número de catálogo P01031 (Isabel de Valois sosteniendo un retrato de Felipe II), disponível em <http://www.museodelprado.es/coleccion/galeria-on-line/galeria-on-line/obra/ isabel-de-valois-tercera-esposa-de-felipe-ii/>; e também Miguel Falomir Faus (1999, p. 402).

74. Ibidem.

75. Retratos em miniatura, geralmente pintados em camafeus, eram usuais na corte de Felipe II. Javier Portús nos relata: "Una entre docenas nos ofrece Francisco Santos en sus Postrimerias del Hombre [1604], donde se insiste el uso y la ubicacion intima de estos objetos, 'pues al tomar el jubón besa um relicário, que atado trae a los ojales, donde tiene el retrato de su dama junto com uno de una imagen;y aunque besa por el lado de la razon, al punto se acuerda de la cautela que está detrás, y la destapa y mira'."; e também que não só o teatro explorava tais cenas, mas também romances como La Dorotea, de Lope de Vega, de 1632. Cf. Javier Portús (2000, p. 191). no peito o retrato daquele que parece ser seu finado marido, D. Rodrigo de Tejada, revelando o afeto e a homenagem ao ente querido. Deve-se mais uma vez ressaltar sua importância ao ser retratada dentro dos mesmos cânones da retratística espanhola dos nobres. Se parece evidente que Sánchez Coello queria ressaltar os elementos opostos entre as retratadas - "señora y servidora, rica y pobre, joven y vieja" -, há também, como afirma Kusche, o desejo de conceder a Magdalena "autonomia" e "dignidade" ao lado de sua ama ${ }^{72}$.

No que se refere ao camafeu, o modelo para o retrato de Isabel Clara Eugenia, além daquele de sua tia Juana de Áustria, é o de sua mãe Isabel de Valois atribuído a Sofonisba Anguissola ${ }^{73}$ (Figura 6). Em sua mão esquerda, a rainha sustenta a efígie do marido possivelmente pintada a partir das realizadas por Alonso Sánchez Coello em dois camafeus feitos para ela ${ }^{74}$. Esse objeto muito em moda como presente ${ }^{75}$, reforçava a relação de afeto entre os casais. No caso de Isabel de Valois, isso não só demonstra a relação íntima, mas confirma a relação de poder que se estabeleceu entre as famílias. A dinastia dos Habsburgo é notada através da efígie e da coluna que aparece no canto da obra, servindo
Figura 6 - Sofonisba Anguissola. Retrato de Isabel de Valois sustentando um retrato de Felipe II, 1561 , óleo sobre tela, $206 \times 123 \mathrm{~cm}$. Museo Nacional del Prado, Madri.




de apoio para as mãos da rainha ao sustentar a miniatura, evidenciando a relação direta entre Isabel e o marido, e sua subordinação a ele.

As famílias de Carlos V e Felipe II serão as primeiras a incorporar tal modelo em sua retratística, sendo não só o grande Imperador da Europa aquele a figurar nas medalhas sustentadas nas mãos e colares dos personagens principais, mas também a efígie de seu filho Felipe II vai aparecer em diversas pinturas, sendo, de fato, a geração deste último aquela a consolidar tal modelo. O gênero do retrato contribuirá, nesse sentido, para estabelecer não somente o vínculo familiar mas também para mostrar a hierarquia entre os retratados e sua dimensão na esfera do poder europeu, além de evidenciar o valor e a virtude dos retratados, tornando-os duplamente um exemplo a ser admirado. Tais retratos fornecem, assim, um modelo precioso, possivelmente retomado por Taunay em 1816, sobretudo no que concerne à tipologia do "retrato dentro do retrato".

Os retratos de Maria Isabel e Maria Francisca de Bragança

Maria Isabel nasceu em Queluz, em 1797. Chegou em 1808 ao Rio de Janeiro, com a família real, e aí permaneceu até o momento de viajar a Madrid, em 1816, para tornar-se rainha daquele território. Era uma peça importante na aliança política entre Portugal e Espanha, tendo desempenhado papel relevante na cultura espanhola do período, tornando-se uma das colaboradoras na fundação do Museu do Prado durante os poucos anos em que viveu em Madrid. Faleceu em 1818 , apenas dois anos depois sua chegada.

Maria Francisca de Assis, nascida em Queluz em 1800, deixa o Brasil em 1816 junto com a irmã rumo ao casamento. Seu papel foi igualmente importante na política ao lado do marido, apoiando-o nas guerras carlistas para ocupação do trono espanhol após a morte de Fernando VII. Porém, assim como a irmã, a vida de Maria Francisca também foi breve, falecendo na Inglaterra em $1834^{76}$

O papel político desempenhado pelas duas princesas é um dos elementos importantes para a realização dos retratos. Diferentes das demais pinturas feitas por Taunay conservadas no Palácio de Queluz, estes retratos das princesas de Bragança são mais bem executados, em todos os sentidos. Maria Isabel (Figura 1) é retratada em meio corpo. Penteada à moda do período, tem os cabelos divididos ao meio e cacheados. $O$ rosto é alvo, pintado de forma delicada; a boca é levemente rosada e está entreaberta. Em sua orelha direita, a princesa porta um brinco de pingente preto, que estabelece um diálogo sutil entre os cabelos e a roupa igualmente negra, mantendo o canal de ligação entre as partes. No centro do retrato, a gola branca de três babados ou colerette se destaca. No peito de Maria Isabel, pende o retrato em miniatura do rei Fernando VII, seu noivo, ao lado da placa da Ordem das Damas Nobres de Santa Isabel ou da Ordem da Cruz Estrelada de Áustria77, e da faixa de Carlos III.

Com algumas variações, o retrato de Maria Francisca (Figura 2) é
76. Após Maria Francisca de Assis falecer na Inglaterra, em 1834, D. Carlos Isidro casa-se com Maria Teresa, a irmã dela, também retratada por Taunay. Esta última, princesa da Beira e filha primogênita de D.JoãoVI e D. Carlota, nasceu em Lisboa, em 1793 , e ficou viúva de D. Pedro Carlos de Bourbon e Bragança em 1812, aos 19 anos de idade, dois anos após o casamento. Da união nasceu Sebastião Gabriel de Bourbon e Bragança, príncipe da Espanha e Portugal, igualmente retratado por Taunay. Em Madri, Maria Teresa, sem êxito, lutará pelos direitos desse seu filho na corte espanhola, tornando-se também aliada de D. Miguel na sucessão do trono português. Faleceu em Trieste em 1874

77. Conforme consta do inventário da obra em Portugal. 
78. O inventário da obra descreve o objeto como um relógio.

79. Cf. Peter Burke (2004, p. 99).

80. Ver François Boucher (2010).

81. Disponível em: <http:// www.getty.edu/art/gettyguide/artObjectDetails?art obj $=923 \&$ handle $=l i>$.

82. Disponível em: <http:// www.philamuseum.org/collections/permanent/82668. html>.

83. Disponível, entre outros, em: <http://www.nantes.fr/ portrait-de-madame-de-senonnes-par-ingres $>$. semelhante ao da irmã na composição. Ela também apresenta o cabelo penteado e dividido, os cachos igualmente the caem na testa, mas em menores proporções volumétricas. $O$ rosto é alvo, o olhar é firme e as sobrancelhas se encontram, diferente da irmã Maria Isabel, cuja doçura no olhar revela uma característica reconhecidamente pública da princesa. No cabelo de Maria Francisca há um pente espanhol, denotando sua relação com o lugar de destino, ou apenas a confirmação de seu pertencimento à família de seu noivo. Carlos Isidro pende em seu peito, em uma miniatura, sobre a faixa de Carlos III, estando logo abaixo aquilo que parece ser um adereço condecorativo, ou mesmo um relógio ${ }^{78}$, símbolo moral do tempo, mas também sinal de riqueza e de alto nível social79. Maria Francisca, como no retrato da irmã, além de apresentar as mesmas insígnias, também apresenta um brinco na orelha direita, ligeiramente maior que aquele de Maria Isabel; e, acima de seu vestido negro, a gola branca e exuberante de dois babados enriquece o retrato, quebrando a concentração de cores escuras. Os dois retratos apresentam-se em fundo abstrato, à maneira das composições neoclássicas do período, almejando um deslocamento da imagem central para fora da tela, enfatizando, assim, sua importância em meio a um cenário neutro.

\section{A indumentária}

Nos dois retratos, sobressaem-se as golas. Ambas são regulares, simétricas e feitas em renda, símbolo da nobreza e moda na Europa do século XVI. François Boucher destaca seu uso na Índia e arredores, e a admiração dos europeus em visita a esses países, tendo levado a moda aos Países Baixos e posteriormente à Espanha, onde passou a ser um acessório diretamente ligado à moda loca ${ }^{80}$. Passou, então, a circular em outros países, notadamente os do norte da Europa, e, também, a ltália e a França. Embora tenha passado por um período de ausência na moda, sobretudo na primeira metade do século XVIII, ela volta com força na segunda metade para o final daquele século, tanto nas roupas masculinas como femininas. Também aparecerá durante o neoclassicismo do início do século XIX, sobretudo no período napoleônico e, mais especificamente, no Consulado. Nesse período, buscam-se elementos históricos e clássicos para a recriação de modas dos séculos anteriores, sobretudo do Renascimento. Nas telas feitas por Jacques-Louis David e seus discípulos diretos, é notória a presença do acessório. Bons exemplos desse emprego são Zénaide et Charlotte Bonaparte ${ }^{81}$, de David, e Mademoiselle Juliette Recamier, de Jean-Antoine Gros. Também duas telas de Jean-Auguste Dominique Ingres - o retrato da Comtesse de Tournon ${ }^{82}$ e o de Madame de Senonnes ${ }^{83}$ - mostram o quanto a collerette e a fraise estavam presentes na moda francesa. Ela continuará ao menos até a primeira metade do século XIX, onde a retomada de elementos góticos dará, sobretudo à fraise, um novo impulso.

Na vestimenta de Maria Francisca, a gola parece aproximar-se mais da moda francesa do século XVIII, mas é evidente sua relação com os modelos 
ibéricos e holandeses. Taunay, cuja filiação ao neoclassicismo não pode deixar de ser destacada, identifica-se também com os pintores holandeses caros à sua formação e presentes nas coleções francesas. Tanto a gola de três babados de Maria Isabel quanto aquela de duas voltas de Maria Francisca são pintadas de forma precisa e realista, à maneira de Frans Hals, Van Dyck e Rubens. Mas também é evidente que Taunay quer mostrar o vínculo natural das retratadas com sua filiação franco-luso-espanhola. Nas coleções portuguesas, podemos ver alguns retratos de senhoras do século XVI com o acessório. Vejam-se o de Isabel Clara Eugenia, feito pelo espanhol Alonso Sánchez Coello e conservado no Museu Nacional de Soares dos Reis; o de D. Joana de Albuquerque (1591), no Museu Nacional do Traje; o de Maria de Portugal e Parma, de autoria de Joris van der Straeten; e o Retrato de Infanta da Casa de Áustria, no Museu Nacional de Arte Antiga de Lisboa. Mas, no que concerne a esse detalhe, chamam a atenção alguns retratos de Carlota Joaquina, executados por João Baptista Ribeiro, que mostram a rainha portando o acessório. Em seus retratos de corpo inteiro, em meio corpo ou em miniatura, sobressaem-se a vestimenta, por vezes negra ou vermelha, e a gola branca. $\bigcirc$ mesmo Nicolas-Antoine Taunay realiza seu retrato em meio corpo, colocando a gola branca em destaque ${ }^{84}$. E, de modo minucioso, o artista repetirá esse detalhe no retrato da Marquesa de Belas, "cujo caráter vivo e móvel é revelado pelas luzes do penteado encaracolado e pelos brilhos brancos da renda do colarinho, como em certos retratos holandeses da época de Frans Hals" ${ }^{\prime \prime}$, como já ressaltou Luciano Migliaccio. $\bigcirc$ detalhe do xale que the cobre metade dos ombros, o vestido negro e, mais uma vez, a presença da marcante gola de renda, aproxima o retrato daqueles das princesas, revelando não só a moda do período mas o cuidado do pintor na execução dos acessórios.

Quanto aos vestidos de Maria Isabel e Maria Francisca, eles são idênticos. As outras princesas de Bragança pintadas por Taunay não apresentam o mesmo vestido de Maria Isabel e Maria Francisca. Elas ora mostram o colo com joias, ora cobrem todo o corpo, com tecido mais leve e colorido. Nos que aqui consideramos como o de Maria Isabel e o de Maria Francisca, as mangas ligeiramente bufantes são compridas, símbolos de decoro, obedecendo à moda do fim do século XVIII, sobretudo do período do Consulado.

Os vestidos iguais reforçam a identidade das irmãs e seus destinos ligados aos irmãos consanguíneos espanhóis, e associam-se aos demais detalhes semelhantes presentes nas duas pinturas. Isso pode ser, no entanto, um indício de que as princesas não posaram para Taunay. $\bigcirc$ pintor pode ter se baseado na pintura de memória do rosto das princesas, ou mesmo em gravuras, e usado o mesmo vestido em um manequim, modelo para os dois retratos, apenas diferenciando-os nos detalhes das golas. Isso nos leva a pensar que a pintura pode ter sido feita após o embarque das duas princesas para a Espanha ${ }^{86}$, com a intenção de que os retratos permanecessem na corte como um símbolo da união das princesas com seus respectivos noivos, também retratados, reforçando as relações de poder entre os países e reavivando, a cada dia, a memória das filhas princesas para a mãe Carlota. A hipótese torna-se mais plausível se levarmos em conta que a Maria Isabel, de Taunay, não é muito semelhante a outros retratos
84. O retrato também pode ser visto em Lilia Schwarcz com Elaine Dias, 2008, assim com os demais retratos das princesas de Bragança.

85. Cf. Luciano Migliaccio (2006, p. 70).

86. As princesas, que deveriam sair do Brasil em fevereiro de 1816 , partiram apenas no dia 3 de julho do mesmo ano. Neste período, Taunay já estava no Brasil. Cf.Angelo Pereira (1946, p. 213). 
87.Ver Javier Portús (2004b).

88. "Hazía una fiesta uno destos [hombres devotos] al santo de su devoción en una iglesia desta Corte, adonde tenía su sepultura con su poco de retablo, y él y su muger se avían mandado retratar en él, vestidos de negro (lo que no acostumbraban el ordinário) con mucha gala, autoridad y devoción."Vicente Carducho, apud Alfonso Pérez Sánchez (2004,p. 200).

89. O retrato está conservado no Museo del Prado, em Madrid. Disponível em <http:// www.museodelprado.es/ coleccion/galeria-on-line/ galeria-on-line/obra/la-emperatriz-maria-de-austria-esposa-de-maximiliano-ii/>.

90. A pintura se conserva na Villa Habsburgo, em Roma.

91. O retrato está no Museo del Prado, em Madrid. Há também outro retrato de Isabel de Valois feito por Pantoja de la Cruz, conservado no Museo del Prado, em que a rainha aparece igualmente vestida de preto.Ver:<http:// www.museodelprado.es/ coleccion/galeria-on-line/ galeria-on-line/obra/isabel-de-valois-tercera-esposa-de-felipe-ii/>

92. A pintura está no Musées Royaux des Beaux-Arts, Bruxelas. Há outro retrato de Joana de Portugal (antes atribuído a Antonio Moro) conservado no Museo del Prado, datado de 1561, onde ela igualmente está de preto.

93. O retrato se conserva no Museo de Bellas Artes de Bilbao. dela pintados posteriormente na Espanha, sobretudo aqueles realizados pelo pintor Vicente e Bernardo López, com exceção do olhar profundo e dócil que se repete neste conjunto, e da brancura de sua pele. Maria Francisca é mais próxima dos retratos realizados em Madrid por Agustín Esteve e Vicente López, sobretudo as sobrancelhas espessas que se ligam uma a outra, embora naquele de López realizado em 1823, a princesa já se apresente como mulher adulta. Naquele de Taunay, era uma adolescente de 16 anos.

Há ainda um elemento importante na escolha dos vestidos. $\bigcirc$ fato de serem pretos está ligado não só à condição de luto que a corte sustentava em razão da morte de $\mathrm{D}$. Maria I, mas pode relacionar-se também à maneira tradicionalmente austera do retrato espanhol, ligada, por sua vez, à retratística flamenga. Tal austeridade foi possivelmente pensada por Taunay como um elemento significativo da nova condição das retratadas. Os retratos espanhóis, ao menos até o final do século XVII, segundo nos relata Pérez Sánchez, apresentarão a cor negra como "color elegante, de la autoridad, de la dignidad, y de la majestad", sendo essa uma regra nos retratos de corte, tanto de homens quanto de mulheres. Evidentemente, no caso feminino, o negro também se associa à viuvez, mas não somente. Pérez Sánchez destaca ainda a contraposição entre o branco das golas e o negro das vestimentas, mantida não só na Espanha como também fora dela, indicando a circulação desse modelo de "gravedad, esa austeridad, esa contención" para os demais países europeus. No caso da Espanha, à austeridade e à contenção proporcionadas pelo negro junta-se a economia de atributos existente nos retratos, embora os poucos elementos sejam extremamente detalhados. Essa "simplicidade" associada à gravidade do negro é também uma característica intrínseca ao retrato flamengo, tradição que foi passada à Espanha no Renascimento, sobretudo no período de Felipe $\mid{ }^{87}$.

Em seus Dialogo, Carducho também comenta o uso do preto no retrato espanhol, evocando aí o retrato "de doação", onde a figura aparece notadamente vestida de negro como símbolos evidentes de sua seriedade e compostura ${ }^{88}$. Em alguns retratos, as rainhas anteriores da península ibérica aparecem de preto, seja como sinal de luto ou como reflexo dessa tradição do retrato de doação convertida em modelo. Em 1551, Antonio Moro pinta Maria de Áustria ${ }^{89} \mathrm{com}$ vestidos pretos inteiramente bordados. A mesma cor aparece no retrato da Infanta Catalina Micaela, Duquesa de Saboya, pintado em 1581 por Pantoja de la Cruzº, e também no Retrato de Isabel de Valois ${ }^{91}$ (Figura 6) hoje atribuído a Sofonisba Anguissola, pintora que deu à retratística espanhola toques preciosos da simbologia italiana.

Nesse quadro de Sofonisba, Isabel, vestida de preto com mangas inteiramente abertas, deixa entrever os braços cobertos com um tecido bege, e segura nas mãos uma miniatura de Felipe II. O retrato foi feito pouco tempo depois de seu casamento com ele, e o uso do preto, no caso, não denota qualquer relação com a morte.

Já em Juana de Portugal [ou Juana de Áustria] con negrita92, feito por Cristóvão Morais em 1552, e no retrato da mesma Juana pintado por Alonso Sánchez Coello93 (Figura 4), ela está vestida de preto em razão de sua viuvez. 
Neste último, Juana carrega um medalhão com a figura de seu irmão, o mesmo Felipe $\|^{94}$. Também há outros retratos em que está vestida de negro levando consigo um medalhão de seu pai, Carlos V95. Viuvez, austeridade e majestade, uma vez que Juana de Áustria tornou-se regente em lugar do pai e do irmão.

Para a retratística de corte, o uso do preto é algo extremamente relevante. Únicas inteiramente vestidas de preto no conjunto de retratos da família Bragança executado por Taunay no Rio de Janeiro, Maria Isabel e Maria Francisca confirmam este elemento essencial presente na retratística europeia. Associada a tal questão, aparecem as miniaturas, tópico de fundamental importância para a composição de seus retratos, como veremos a seguir.

As miniaturas de Fernando VII e Carlos Maria Isidro de Bourbon

Um dos atributos mais importantes presentes nas composições dos quadros de Maria Isabel e Maria Francisca são os pequenos retratos que elas levam em seus peitos. Maria Isabel traz consigo a imagem em miniatura do rei Fernando VII; e Maria Francisca, a de Carlos Maria Isidro, irmão do rei Fernando. Selava-se assim, por meio do "retrato dentro do retrato", a relação íntima estabelecida entre os Bragança de Portugal e os Bourbon na Espanha.

As duas figuras em miniatura penduradas como pingentes em delicados colares junto ao corpo das duas princesas evidenciam a intimidade entre as retratadas principais e suas imediatas correspondências. Suas composições de grande semelhança reforçam mais uma vez o fato de serem as pinturas um pendant. A importância do casamento duplo, da aliança política, e o vínculo afetivo entre as duas princesas e os retratados, igualmente irmãos, era confirmada pelas miniaturas.

Fernando VII e Carlos Maria Isidro aparecem sob a forma de bustos, com insígnias e uniformes militares. A efígie de Fernando VII pode ter sido pintada por Taunay por meio de gravuras dos retratos do rei realizadas em 1814 , data de seu retorno a Madrid após o período napoleônico. Podem ter sido os modelos gravados e utilizados pelo pintor no Rio de Janeiro tanto os retratos feitos por Goya nesse período (bastante próximos ao semblante de Fernando VII pintado por Taunay), como aqueles realizados por Vicente Pérez. Os retratos de Fernando VII feitos por Goya, tanto em uniforme militar no acampamento quanto em trajes majestáticos (de resto muito semelhantes por se tratarem de um único modelo96), são bastante próximos daqueles de Taunay. Bem menos próximos, sobretudo na semelhança do rosto, estão os retratos feitos por Vicente López, que se tornou o pintor preferido do rei a partir de 1814 . Apesar da aproximação a estes retratos de corpo inteiro feitos por Goya, o semblante de Fernando pintado por Taunay está mais próximo daquele que o pintor espanhol fez, também em 1814, de meio corpo $^{97}$, embora neste o rei esteja vestido com o manto real e não com o aparato militar usado na miniatura de Taunay. Reconhecemos o quanto seria mais difícil para Taunay conhecer os retratos realizados por Goya em 1814, mas é muito
94. Ver Juan Miguel Serrera (1990).

95.A pintura está conservada no Isabela Stewart Gardner Collection, em Boston.

96. O retrato em que Goya o pintou em trajes majestáticos serviu de modelo para a realização daquele no acampamento militar. Fernando VII mantém exatamente a mesma pose no espaço, mudam apenas a vestimenta $\mathrm{e}$ o cenário que o envolvem. Disponíveis em: <http:// www.museodelprado.es/ coleccion/galeria-on-line/ galeria-on-line/obra/el-rey-fernando-vii-con-manto-real/>; <http://www.museodelprado.es/coleccion/ galeria-on-line/galeria-on-line/obra/fernando-vii-ante-un-campamento/>

97. Este retrato, de meio corpo, com manto real está em Pamplona, na Diputación Foral de Navarra. Cf. sobretudo Manuela Mena Marqués (2008, p. 374-375) 
provável que tenham sido divulgados em gravuras. Fernando VIl aparece em trajes militares e traz o Tosão de Ouro, elemento significativo para identificá-lo na miniatura, além de semelhanças físicas com outros retratos. Isto pode afastar, assim, qualquer hipótese de identificar a miniatura como sendo de Carlos Maria Isidro, levando, mais uma vez, a considerarmos como de Maria Isabel o retrato catalogado como de Maria Francisca.

Entre os retratos de Carlos Maria Isidro, são de especial importância aqueles realizados pelo pintor Vicente López, que, além de Carlos lem três diferentes versões: duas conservadas na Real Academia de San Fernando, outra no Museu do Prado), também retratou diversos membros da corte, inclusive nossas princesas e o próprio rei, seu irmão. Em todas as versões, Isidro aparece com o uniforme de "capitán general de carabineros" e com a faixa de Carlos III. Uma das versões da Real Academia de San Fernando, de 1814, segundo nos relata José Luis Díez, autor do Catalogue raisonné de Vicente López ${ }^{98}$, foi posteriormente gravada (em forma de busto, junto à efígie de Fernando VIII) por Manuel Alegre a partir de desenhos de Antonio Guerreiro. Outra versão /de 1823) também acabou gerando várias gravuras em formato de busto99. Certamente não foi essa a versão utilizada por Taunay para fazer o retrato de Carlos Isidro no peito da princesa, mas ele pode ter se baseado na gravura de Manuel López, amplamente divulgada junto com a efígie do rei no momento em que a família real retorna a Madrid, em 1814. Em Taunay, Carlos Isidro está com o mesmo uniforme e a faixa de Carlos III, além do típico bigode e do cabelo que the vem à testa.

A presença de miniaturas com as efígies de figuras políticas como atributo do retratado principal tornou-se algo comum à retratística espanhola, sobretudo entre os séculos XVI e XVII, como já ressaltamos em tópico anterior. Nicolas-Antoine Taunay parece aproximar-se dessa maneira de compor o retrato para realizar as pinturas das duas princesas com destino à corte espanhola. Porém, é certo também que o artista terá mais um modelo a ser imitado, como veremos adiante.

O retrato dentro do retrato

No caso do artifício do retrato dentro do retrato, utilizado nas telas das princesas de Bragança, é possível que Taunay tenha em mente um retrato de família, isto é, um exemplo que the permita seguir esse bem sucedido modelo, já consolidado na história do retrato. Trata-se do retrato de Carlota Joaquina (Figura 7), hoje conservado no Palácio Nacional da Ajuda, em Lisboa, de autoria anônima. A rainha, elegantemente vestida em vermelho, faz-se acompanhar de uma série de atributos. Alguns deles se ressaltam, como a presença de um desenho e de um pincel, mostrando a ligação da princesa com as artes e o fato de princesas, dentro da tradição europeia, aprenderem o ofício das artes. Em seu peito, ela porta a efígie de D. João VI, pendente como uma joia, segurando-a de 




Figura 7 - Autor desconhecido. Retrato de Carlota Joaquina, s.d., óleo, $92 \times 74 \mathrm{~cm}$. Palácio Nacional da Ajuda, Lisboa.

modo enfático no centro da composição. Sabemos que o mesmo retrato de Carlota Joaquina foi copiado no Rio de Janeiro, com ligeiras modificações, pelo pintor Manoel Dias de Oliveira, evidenciando a vontade da rainha em mostrar, aos seus súditos, através da pintura, a sua condição, seu caráter forte e sua ligação com D. João VI, enfatizada pela presença da miniatura. No quadro de Manoel Dias, a rainha exibe o mesmo vestido constante naquele de autor anônimo, e, além de segurar o retrato de D. João, traz, ao lado dessa miniatura, a Cruz Estrelada dos Áustria (Habsburgo).

Nesse ponto, é necessária uma pequena digressão. Chegamos ao nosso impasse sobre a possível encomenda da rainha a Taunay e a questão pendente desde no início deste artigo: teria sido uma encomenda de Carlota? Nicolas-Antoine Taunay, depois de sua chegada ao Brasil em 1816 , vai depararse com uma série de eventos políticos e dificuldades que estão na ordem do dia: o atraso na fundação da Escola de Ciências, Artes e Ofícios, da qual era professor; a instabilidade provocada por um reino que acabara de formar-se - o Reino de Portugal, Brasil e Algarves; a morte de D. Maria I e ocupação do trono por D. João Vl; e as negociações do casamento de D. Pedro e D. Leopoldina. Dentro desse contexto, como já ressaltamos, Taunay pretende encontrar um trabalho condizente com sua formação artística e havia ainda a necessidade de sustento após a chegada na corte, visto o futuro incerto do projeto artístico e a necessidade de sustentar sua numerosa família, como já bem relatou Lilia Schwarcz. É nesse sentido que o conjunto de retratos realizados para a família 
100. Ver Lilia Schwarcz (2008).

101. Disponível em:<http:// www.museodelprado.es/ coleccion/galeria-on-line/ galeria-on-line/obra/la-condesa-de-chinchon/>. de D. Carlota pode ter se originado a partir de duas hipóteses: encomenda ou presente. Não podemos ainda afirmar a ocorrência da encomenda, pois faltam documentos que comprovem tal fato. Além disso, para tal empresa, Carlota poderia ter recorrido a outros pintores da corte, como o próprio Manoel Dias de Oliveira, que já havia feito a cópia de seu retrato. A hipótese de presente do pintor vem ao encontro da busca de um lugar na corte dos Bragança, como acontecera provavelmente com o quadro da Quinta da Boa Vista, já citado. Nem mesmo os inventários do Palácio Nacional de Queluz confirmam a encomenda, uma vez que, até pouco tempo, essas pinturas eram consideradas como de "autoria anônima", sendo Claudine Lebrun-Jouve quem as atribuiu a Nicolas-Antoine Taunay. É possível que, para sua entrada definitiva na corte, esta fosse a cartada final de Taunay, garantindo seu futuro e também de seus filhos no Rio de Janeiro, segundo nos relata, novamente, Lilia Schwarcz ${ }^{100}$.

Assim, na realização dos dois retratos em questão, dada a presença das miniaturas, é provável que Taunay tenha se baseado no retrato de Carlota. Este, no entanto, está imediatamente ligado à retratística tradicional espanhola, cultura de que, como uma Bourbon, a rainha fazia parte. A tipologia do retrato dentro do retrato tornou-se bastante comum na Espanha, mesmo o modelo sendo originário da Itália, como enfatizado antes, e daí se difundindo de maneira espantosa. Também já vimos como tal tipologia se desenvolveu na família de Carlos V e de seu filho Felipe II, tornando-se um modelo bem sucedido na representação dos nobres e dos homens de Estado. Daí, porém, decorre outra pergunta: por que Taunay não pensaria, nesse sentido, como um modelo para os retratos das princesas de Bragança, na retratística de um pintor espanhol como Francisco de Goya, mais próximo à sua época e aos Bourbon? Para a realização da miniatura de Fernando VII, Taunay pode ter-se baseado em gravuras de Goya, mas a composição principal, isto é, a maneira de representação das retratadas principais distancia-se do modelo daquele artista.

No conjunto de retratos feitos por Goya, além daquele de Fernando VII (já citado) e do famoso retrato coletivo da família de Carlos IV, poderíamos assinalar dois outros quadros em que o pintor utiliza o retrato dentro do retrato, elemento que Taunay repete em sua obra. $\bigcirc$ primeiro deles é o Retrato da Condesa de Chinchón, realizado em 1800 ${ }^{101}$. Nele, Doña María Teresa de Borbón y Vallabriga, marquesa de Boadilla del Monte e condessa de Chinchón aparece de corpo inteiro em uma composição de fundo neutro, vestida de modo elegante, portando na cabeça um delicado arranjo com espigas de trigo, símbolo da fertilidade e, na mão esquerda, o anel com a efígie do marido Don Manuel Godoy, figura importante na corte dos Bourbon. $O$ detalhe, pequeno e delicado, confere à retratada sua ligação afetiva e política com o marido. Outro desses retratos em que o aparato surge é aquele de Maria Vicenta de Solís Vignancourt Lasso de la Vega, ou condessa Fernan Nuñez, feito por Goya em 1803. Nele a retratada aparece de corpo inteiro, sentada em meio à paisagem, numa vestimenta negra com mangas amarelas e detalhes em dourado, trazendo adereços na cabeça e um leque na mão direita. No centro, em miniatura quadrada (mesmo 
formato que aparece nas telas das princesas de Taunayl, pende o retrato do marido, o conde Fernan Nuñez, com banda de Carlos III. Este retrato é vivaz e colorido, refletindo, de certo modo, um bom momento da produção do pintor em suas encomendas aristocráticas ${ }^{102}$.

A composição segue o modelo espanhol dos séculos XVI e XVII no que se refere à miniatura. Porém, é pouco provável que Taunay o tenha visto. Mas certamente o pintor sabe dos retratos reais feitos por Goya e os viu em gravuras, sobretudo aqueles relativos aos Bourbon realizados ainda no século XVIII e início do XIX: o da rainha Maria Luisa, o já citado retrato da família de Carlos IV e os retratos de Fernando VII.

Robert Rosenblum destaca o quanto Goya se vincula, como retratista dos Bourbon, ao destronamento político e também pictórico de suas pinturas no início do século XIX, levando aos retratos não só o realismo da fealdade da família, mas também a atmosfera de falência que abalava a corte espanhola. Isto se evidencia não só no retrato da família real - com sua "falta de gracia de las diversas posturas [...], una imagen de flaqueza y verdad humanas frente a la cual el concepto de la monarquía de derecho divino es sólo um recuerdo lejano de algo que la Revolución francesa erradicó" 103 - mas nos retratos de Fernando VII, que obedecem a um esquema pronto, desprovido de grandeza, símbolo máximo de apatia protocolar, sem grandes significações além de um "amargo" protótipo de retrato real, tantas vezes repetido.

Para realizar os retratos das princesas de Bragança, Taunay se distancia da aparente ironia de Goya, da amargura e do ressentimento presentes nos retratos da família Bourbon. Não há razão para vinculá-las a esse modelo fracassado da retratística de Fernando VII (ainda que elas se liguem a ele). Além disso, sabe-se que Goya, retratista oficial dos Bourbon e ativo sobretudo na corte de Carlos IV, vai sair de seu posto de primeiro Pintor de Câmara de Fernando VII, retirando-se definitivamente da cena de corte. Mais ainda, também é pública a predileção de Fernando VII pela retratística de Vicente López Portaña, preferindo seus retratos aos de Goya, e fazendo deste o "primeiro" pintor de sua corte.

A representação da decadência e a fealdade dos retratos feitos por Goya, e a predileção de Fernando VII por López, podem ter sido importantes para afastar Taunay de uma escolha voltada para o modelo de Goya na retratística dos Bourbon, preferindo o bem sucedido modelo dos Áustria espanhóis. Os retratos de Juana de Áustria, Isabel Clara Eugênia e Isabel de Valois mostram o sucesso da composição na forte representação feminina ligada de modo íntimo e político à pequena miniatura retratada, evidenciado a relação de subordinação, de aliança e de afeto. Mais ainda, evidencia o poder político familiar que dominava a Europa e estabelecia, ao mesmo tempo, novas formas de pensar o gênero do retrato de Estado, o trânsito de artistas na corte, o sistema de encomendas, e a circulação de modelos artísticos. As funções do retrato ganham, assim, valores de grande monta e perpetuam-se por outras épocas, países e escolas artísticas.
102. O retrato está conservado em coleção particular. Cf. Manuela Mena Marqués (2008, p. 198).

103. Cf. Robert Rosenblum (2004, p. 158). 
104. Agradeço a Paulo Cesar Garcez Marins por lembrar-me deste retrato e também daquele da Condessa de Chinchón, de Goya. Os retratos da infanta Margarita feitos por Velazquez estão disponíveis em: <http://www. museodelprado.es/en/the-collection/online-gallery/ on-line-gallery/>
Este último é o modelo que imediatamente se associa aos retratos de Carlota Joaquina, onde se procura seguir esse mesmo universo de atributos, estabelecendo uma ligação com sua força política, feminina e artística. É bastante plausível, assim, que o francês Taunay tenha seguido tal preferência (ditada pela rainha) para a realização das pinturas das princesas de Bragança no Brasil. Essa hipótese se reforça, ainda, pelo fato de Carlota, na produção de outros retratos seus, ter confirmado essa inclinação para a retratística dos Áustria na Espanha. Um primeiro quadro em que isso é perceptível é aquele feito por Mariano Maella, um dos grandes pintores do século XVIII espanhol, pintor de câmara de Carlos IV e mestre do célebre Vicente López, o preferido de Fernando. No retrato feito por Maella, a rainha porta vestido de saia bastante larga, à semelhança da Infanta Margarita tanto nas telas feitas por Velázquez quanto naquelas de Juan Bautista Martinez del Mazo ${ }^{104}$. Além desse, há outro exemplo interessante, também referente à mesma Infanta. Trata-se do retrato equestre de Carlota Joaquina feito por Domingos António de Sequeira (Figura 8), hoje conservado no Museu Imperial, em Petrópolis, pendant do retrato também equestre de $D$. João $V I$ realizado pelo mesmo pintor. Elegantemente vestida e sentada de lado em seu cavalo, D. Carlota
Figura 8 - Domingos António de Sequeira. Retrato de Carlota Joaquina, s.d, óleo sobre tela, $0,60 \times 0,51 \mathrm{~cm}$. Museu Imperial, Petrópolis.



Anais do Museu Paulista.v. 19. n.2. jul.-dez. 2011. 
está em posição semelhante à de Margarita de Áustria no retrato equestre pintado por Velázquez entre 1628 e $1635^{105}$. Ao retratá-la dessa maneira, Velázquez identificava sua continuidade dinástica junto a Felipe III, Felipe IV, Isabel de Bourbon e Baltasar, todos representados a cavalo. Em suas pretensões na corte europeia, sobretudo no século XIX, talvez o mesmo se passasse com Carlota, e esse desejo se refletisse, em 1816 , nos retratos de suas filhas.

Confirmando sua eficácia, a tipologia do retrato dentro do retrato novamente vai aparecer no Brasil, na mesma família Bragança e nesse mesmo período. Em alguns retratos, a Imperatriz Leopoldina aparece portando a miniatura do Imperador em seu peito. Jean-Baptiste Debret já fizera, em suas aquarelas e gravuras, o retrato da Imperatriz em forma de busto e de corpo inteiro, portando a miniatura de D. Pedro I no peito ${ }^{106}$. $\bigcirc$ mesmo se passara com Julien Pallière também no retrato de Leopoldina, a ele recentemente atribuído ${ }^{107}$, portando a efígie do marido. Uma outra tela em que novamente o atributo é evidente será o Retrato de D. Pedro I e Dona Leopoldina na Roda dos Expostos ${ }^{108}$. Além de D. Pedro aparecer retratado de corpo inteiro ao lado dela na composição, Leopoldina também leva o retrato do marido no peito, confirmando duplamente sua ligação com a esposa. Mais tarde, vai ser Amélia Beauharnais Leuchtenberg, a segunda esposa, quem portará o retrato de D. Pedro, mostrando o novo enlace e afirmando sua posição ${ }^{109}$.

Ainda no que refere à presença junto ao peito da esposa do retrato em miniatura do marido, e sua circulação no século XIX, temos um exemplo próximo a nós. $\bigcirc$ atributo do camafeu aparece também em um retrato paulista, em possível desdobramento da retratística ibérica influenciando os pintores brasileiros e estrangeiros no Brasil. $\bigcirc$ Retrato de Francisca Miquelina de Souza Queiroz (Figura 9), de autoria desconhecida e hoje conservado no Museu Paulista ${ }^{10}$, mostra a personagem retratada (filha do célebre Brigadeiro Luis Antonio) segurando uma efígie em miniatura de seu marido, o militar Francisco Ignácio de Sousa Queiroz. A miniatura existente na composição é idêntica a um retrato dele, com as mesmas dimensões daquele de Francisca, também conservado no Museu Paulista, e possivelmente realizado pelo mesmo pintor (Figura 10). Ambos os retratos parecem ter sido feitos a partir de uma só encomenda, evidenciando a ligação entre o casal, sua união e a força do nome da família. Francisca Miquelina traz a miniatura pendente em um colar junto ao peito, como se fosse uma joia preciosa, confirmando sua relação íntima e familiar com o retratado. Isto prova mais uma vez a circulação de um modelo bem sucedido da retratística europeia de caráter familiar e da confirmação das relações de afeto e submissão entre os retratados.

Dentro da concepção do retrato dentro do retrato, da dependência que se estabelece entre ambos os retratados, vai ter grande valor - sobretudo, na composição dos retratos espanhóis - o atributo do camafeu e das pequenas pinturas presente junto às figuras principais. Tal elemento, entre os poucos que conferem valor ao retratado, é uma das fortes características da retratística que se estabelece desde a época de Carlos V e Felipe II, ainda que lá não tenha nascido. Voltamos a ressaltar que a composição do retrato segue rumos importantes
105. O retrato está conservado no Museo Nacional de Prado.]

106. Cf. Júlio Bandeira e Pedro Correa do Lago (2009, p. $333,335,611)$

107. Júlio Bandeira, Pedro Correa do Lago e Ana Pessoa (2011, p. 110)

108. O retrato é atribuído a Simplício Rodrigues de Sá mas esta autoria única é hoje contestada por Júlio Bandeira, Pedro Correa do Lago e Ana Pessoa, como sendo, possivelmente, um trabalho de dupla autoria, com Julien Pallière; cf. Júlio Bandeira, Pedro Correa do Lago e Ana Pessoa (2011, p. 179).

109. Ver: <http://www.matriznet.imc-ip.pt/MatrizNet/ Objectos/ObjectosConsultar.aspx?IdReg=998518>.

110. O retrato está reproduzido em Maria Lucília Viveiros Araújo (2004, p. 152). 


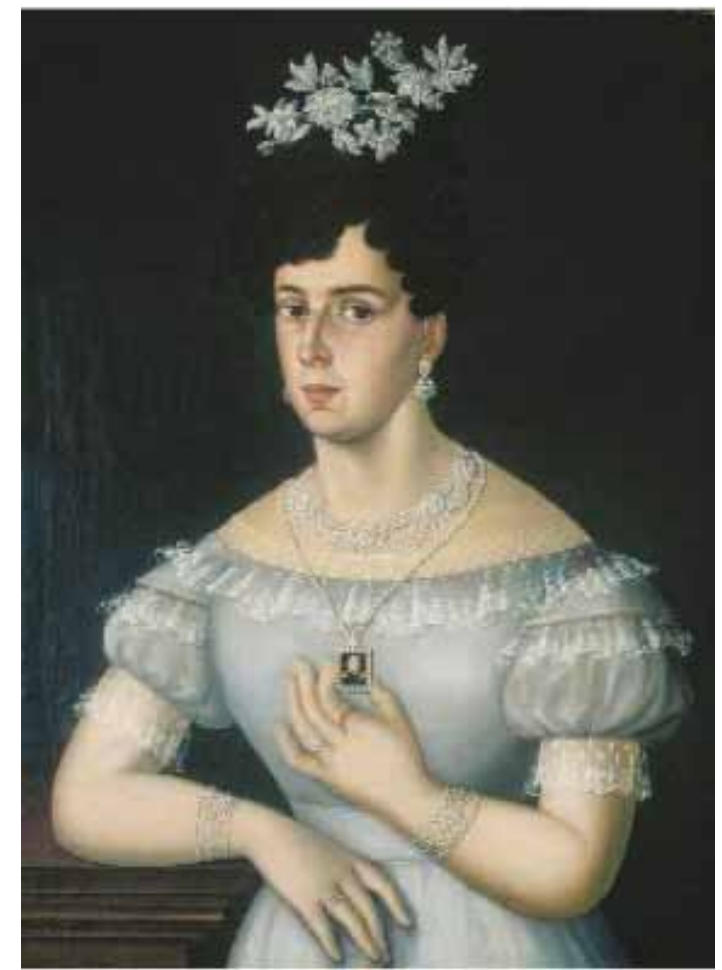

Figura 9 - Autor desconhecido. Retrato de Francisca Miquelina de Souza Queiroz, s.d, óleo sobre tela, $81 \times 60 \mathrm{~cm}$. Museu Paulista da USP, São Paulo.

Figura 10 - Autor desconhecido. Retrato de Francisco Inácio de Souza Queiroz, s.d, óleo sobre tela, óleo sobre tela, 81 × 60 cm. Museu Paulista da USP, São Paulo.

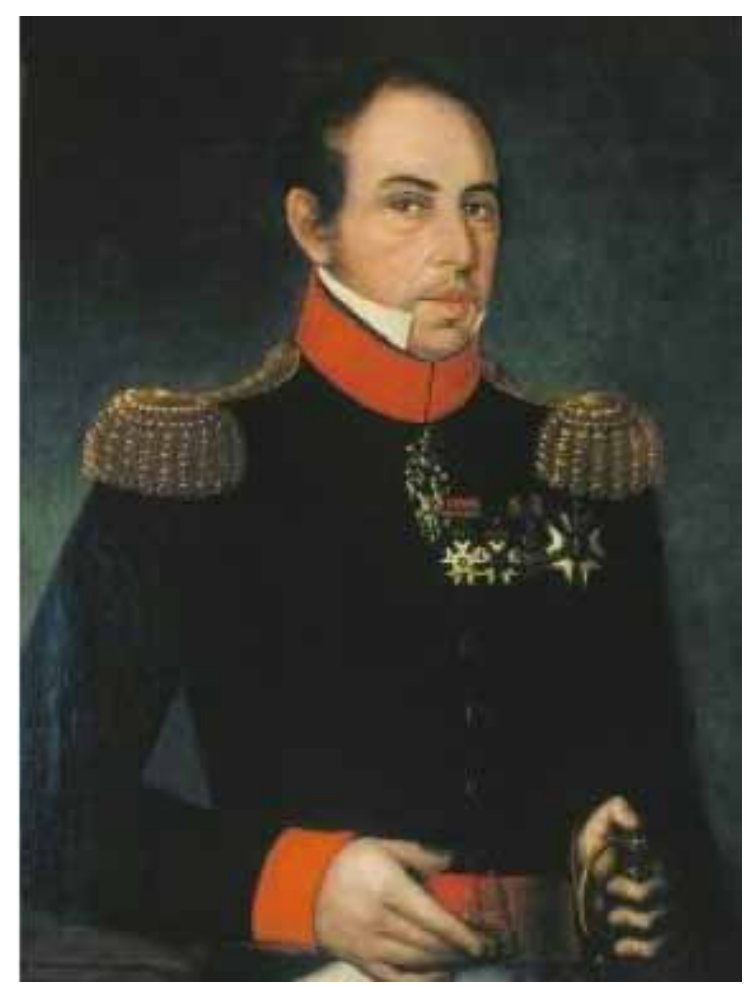


nesse período. Os atributos são poucos, mas os existentes, como os camafeus, são significativos para mostrar a força política da família. Além disso - e também já enfatizado -, o ambiente e vestimenta austeros, o uso do preto, o olhar fixo e determinado dos retratados, somados às joias pendentes com miniaturas, contribuem para consolidar uma fórmula de composição do retrato de personagens nobres, tornando-se uma espécie de modelo para outras dinastias. Esse é um elemento significativo da retratística dos Áustria que aparece na composição desses dois retratos das princesas de Bragança pintados por Taunay.

Considerações finais sobre as escolhas de Taunay

Realizados nos áureos tempos das cortes de Carlos V e Felipe II, os retratos de Juana de Áustria, Isabel Clara Eugênia e Isabel de Valois são, portanto, exemplos certeiros de uma tipologia bem sucedida não só no sentido da propaganda política dos figurados mas da força e firmeza dos retratados pertencentes a essas famílias. E não somente. Para entender sua composição, suas referências, seu significado e suas funções, é necessário retomar e analisar modelos, sobretudo aqueles relativos ao Renascimento, mas transformados, na corte e na escola artística espanhola, associados às suas referências flamengas e italianas. Nesse sentido, a indumentária, o retrato dentro do retrato e a poderosa função do retrato nas referidas cortes, com seus principais artistas são de extrema importância para entendermos a possível opção de Taunay, que consequentemente se desdobra nas cortes portuguesa e espanhola dos Bragança e Bourbon.

Em meio a tais escolhas, é fundamental, ainda, destacar a escola francesa, em razão da própria filiação do pintor. Já mencionamos os retratos feitos pela escola davidiana e sua relação com a moda francesa do período. A questão do fundo neutro é algo também presente nas composições neoclássicas, sendo um elemento importante na economia decorativa proposta pelos artistas que, ao basearem-se no modelo antigo, tratam de limpar os aparatos da composição, centrando a cena nas virtudes do retratado.

Para a composição dos retratos por nós considerados, neste artigo, como sendo de Maria Isabel e Maria Francisca, Taunay utiliza-se, assim, de uma mescla de elementos "simples", mas carregados de valores simbólicos. Como mencionamos, ter o retrato de Carlota como modelo primevo é um indício evidente. Tal modelo parece, dessa forma, transitar por outras composições importantes dentro da história da retratística na Espanha, em que o modelo dos Áustria é extremamente relevante. $\bigcirc$ pintor francês coloca, nas composições consideradas, elementos próximos a essa fórmula, ainda que as figuras estejam a meio corpo e não de corpo inteiro, pose mais comum aos retratos da família de Carlos V e Felipe II. $\bigcirc$ meio corpo é bastante presente na retratística do neoclassicismo, sobretudo em artistas como François Gérard ou aqueles mais próximos a Taunay, como Isabey e Boilly. Vê-se, assim, uma série de elementos advindos não só de importantes escolas artísticas, mas de famílias e de sua 
história política associados às escolhas estratégicas, estéticas e intelectuais para um resultado coerente à nova condição das retratadas.

No retrato que Taunay fez de Carlota, e naqueles por nós considerados como de Maria Isabel e de Maria Francisca, aparecem, com força, a austeridade, o uso do preto, a presença das golas. A imponência de suas poses, o caráter frio da composição associado ao fundo neutro são igualmente elementos que parecem ter sido transportados da distante retratística dos Áustria diretamente para a corte dos Bragança-Bourbon. À economia neoclássica de Taunay na composição, característica também inerente ao neoclassicismo, juntam-se os tons negros e as golas, sendo essas últimas elementos absolutamente perceptíveis nas composições. Somam-se, ainda, apenas elementos, poucos e essenciais - insígnias, faixa e miniatura -, que as associam às casas Bragança e Bourbon. Esta conjunção de elementos evidencia, assim, a função social do retrato nessas cortes, cumprindo não somente o papel de homenagem aos matrimônios, mas também de confirmação de suas novas posições.

Taunay parece, portanto, ir além, tratando esses dois retratos como uma pesquisa, uma estratégia bem pensada e articulada para aproximar-se de Carlota Joaquina e convencê-la de sua capacidade artística. Ele, que buscava com tanto empenho um lugar de destaque no Rio de Janeiro, pode ter depositado nesses retratos as fichas de sua entrada definitiva como pintor da corte dos Bragança, centrando seus esforços em Carlota Joaquina, por via desses retratos, qualquer que seja a hipótese: da encomenda ou de um presente à rainha.

Eternizadas pelo retrato, Maria Isabel e Maria Francisca foram peças importantes nesta estratégia que se delineia por meio de uma composição salpicada de elementos artísticos e advinda, sobretudo, da tradição espanhola com suas fundamentais referências visuais.

\section{REFERÊNCIAS}

ALBERTI, Leon B. Da pintura. Campinas: Editora da Unicamp, 1996.

BANDEIRA, Júlio; CORREA DO LAGO, Pedro. Debret e o Brasil. Rio de Janeiro: Capivara, 2009. ; PESSOA,Ana. Pallière e o Brasil. Rio de Janeiro: Capivara, 2011.

BOUCHER, François. História do vestuário no ocidente. São Paulo: Cosac Naify, 2010.

BROWN, Jonathan. La monarquia española y el retrato de aparato de 1500 a 1800. In:ARGULLOL, Rafael et al. El Retrato. Barcelona: Galaxia Gutenberg; Círculo de Lectores, 2004.

.Pintura na Espanha. 1500-1700. São Paulo: Cosac Naify, 2001.

BURKE, Peter. A fabricação do rei. A construção da imagem pública de Luís XIV. Rio de Janeiro: Jorge Zahar, 1994.

Testemunba ocular: história e imagem. Florianópolis: Edusc, 2004. 
CAMPBELL, Lorne. Renaissance portraits. New York:Yale University Press, 1990.

CARVALHO SOUZA, Iara Lis. Pátria coroada. O Brasil como corpo político autônomo 1780-1831. São Paulo: Fundação Editora da Unesp, 1999.

CASTELNUOVO, Enrico. Retrato e sociedade na arte Italiana. São Paulo: Companhia das Letras, 2006.

CHASTEL,André. Fables, formes, figures. Paris: Flammarion, 2000. 2 v.

CHECA CREMADES, Fernando. Felipe II. Un monarca y su época. Un principe del Renacimiento: catálogo. Madrid: Museo del Prado, 1999.

; FALOMIR FAUS, Miguel; PORTÚS, Javier (Org.). Carlos V. Retratos de família: catálogo. Madrid: Sociedad estatal para la Conmemoración de los Centenarios de Felipe II y Carlos V; Museo Nacional del Prado, 2000.

CÍCERO. Oeuvres Complètes de Cicéron, 2. Paris: J. J. Dubochet, 1840.

CORREIA DO LAGO, Pedro. Taunay e o Brasil. Obra completa, 1816-1821. Rio de Janeiro: Capivara, 2008.

DIDEROT. Essais sur la peinture. Salons de 1759, 1761, 1763. Paris: Hermann, 2003.

DIAS, Elaine. Félix-Émile Taunay. Cidade e natureza no Brasil. 2005.Tese (Doutorado em História) - Instituto de Filosofia e Ciências Humanas da Universidade Estadual de Campinas, 2005a.

Uma carta de Jean-Baptiste Debret ao Camarade de La Fontaine na Bibliothèque de l'Inha (França): novos relatos para a história da Missão Artística Francesa no Brasil. Revista de História da Arte e Arqueologia, Campinas, n. 5, dez. 2005b.

Correspondências entre Joachim Le Breton e a corte portuguesa na Europa. O nascimento da Missão Artística de 1816. Anais do Museu Paulista, São Paulo, v. 14, n. 2, p. 301-313, jul.-dez. 2006.

Paisagem e academia. Félix-Émile Taunay e o Brasil 1824-1851. Campinas: Editora da Unicamp, 2009.

DIEZ, José Luiz. Vicente Lopez (1772-1850). Catálogo Razonado. Madrid: Doce Calles, 1999.

FAGGIN, Giorgio. La obra pictórica completa de Memling. Madrid: Noguer, 1973.

FALCIANI, Carlo; NATALI,Antonio. Bronzino.Artist and poet at the court of the Médici. Firenze: Mandragora, 2010.

FALOMIR FAUS, Miguel. Imagenes del poder y evocaciones de la memória. Uso y funciones del retrato en la corte de Carlos V. In: CHECA CREMADES, Fernando. Felipe II. Un monarca y su época. Un principe del renacimiento: catálogo. Madrid: Museo Nacional del Prado, 1999.

El retrato del Renacimiento: catálogo. Madrid: Museo Nacional del Prado, 2008.

FÉLIBIEN,André. Entretiens sur la vie et les ouvrages des plus excellents peintres anciens et modernes: Paris: S. Marbre-Cramoisy,1686-1688. 5v.

Annals of Museu Paulista. v. 19. n.1. July.-Dec. 2011. 
FLETCHER, Jeniifer. El retrato Renacentista: funciones, usos y exhibición. In: FALOMIR FAUS, Miguel. $E l$ retrato del Renacimiento: catálogo. Madrid: Museo Nacional del Prado, 2008.

GALLEGO, Julian. El cuadro dentro del cuadro. Madrid: Catedra, 1978.

JORDAN,Annemarie. Retrato de corte em Portugal. O legado de Antonio Moro. Lisboa: Quetzal, 1994.

KUSCHE, Maria.Retratos e retratadores. Alonso Sánchez Coello y sus competidores Sofonisba Anguissola, Jorge de la Rúa y Rolán Moys. Madrid:Fundación de Apoyo a la Historia del Arte Hispánico, 2003.

LANE, Barbara.Hans Memling. Master painter in fifteenth century Bruges. New York:Harvey Miller, 2009.

LEBRUN-JOUVE, Claudine. Nicolas-Antoine Taunay 1755-1830. Paris:Arthena, 2003.

LIGHTBOWN, Ronald. Sandro Botticelli. Complete catalogue, 2. London: Paul Elek, 1978.

MENA MARQUÉS, Manuela. Goya en tiempos de guerra: catálogo. Madrid: Museo Nacional del Prado, 2008.

MIGLIACCIO, Luciano.A iconografia nacional na Coleção Brasiliana. In: FUNDAÇÃO ESCOLAR. Coleção Brasiliana: catálogo. São Paulo:Via Impressa Edições de Arte, 2006.

MONNERET, Sophie. David et le neoclassicisme. Paris:Terrail Pierre, 1998.

MUSEO d'Arte Antica del Castello Sforzesco. Pinacoteca, 1: catálogo. Milano: Mondadori Electa, 1997.5 v. (Musei e gallerie di Milano).

PEDROSA, Mário. Da Missão Francesa: seus obstáculos políticos. In:ARANTES, Otília B. F. (Org.). Obras completas de Mário Pedrosa, 10. São Paulo: Edusp, 1995.

PEREIRA,Angelo. Os filbos d'El Rey D. João VI. Lisboa: ENP, 1946.

PÉREZ SÁNCHEZ,Alfonso E. El retrato clásico español. In:ARGULLOL, Rafael et al. El Retrato: Barcelona: Galaxia Gutenberg; Círculo de Lectores, 2004.

PERRAULT, Charles. La Peinture. Poème. Paris: François Léonard, 1667.

PISCICELLI, Enrica G;TARPINO, Antonella (Org.). Encyclopédie de l'Art. Paris: Librairie Générale Française, 1991.

POLLEROSS, Friedrich. Entre 'majestas' y 'modestas': Sobre la representación del emperador Leopoldo I. In:CHECA CREMADES, Fernando; PATRIMONIO NACIONAL. Cortes del Barroco. De Bernini y Velázquez a Luca Giordano. Madrid: Seacex, 2003.

POMMIER, Édouard. Théories du portrait. De la Renaissance aux Lumière. Paris: Gallimard, 1998.

PORTUS, Javier. Soy tu hechura. Un ensayo sobre las fronteras del retrato cortesano en España.In:CHECA CREMADES, Fernando; FALOMIR FAUS, Miguel; PORTÚS, Javier (Org.). Carlos V. Retratos de Familia: catálogo. Madrid: Museo Nacional del Prado, 2000.

."The varied fortunes of the portrait in Spain" In: .The Spanish portrait from El Greco to Picasso: catálogo. London: Scala, $2004 a$.

The Spanish portrait from El Greco to Picasso: catálogo. London: Scala, 2004b. 
ROSENBLUM, Robert. Goya frente a David: la muerte del retrato regio. In:ARGULLOL, Rafael et al. El Retrato. Barcelona: Galaxia Gutenberg; Círculo de Lectores, 2004.

SCHIANCHI, Lucia F. (Org.). Galleria Nazionale di Parma. Catalogo delle opere del Cinquecento e iconografia farnesiana: catálogo. Milano: Franco Maria Ricci, 1998.

SCHWARCZ, Lilia. As barbas do imperador. São Paulo: Companhia das Letras, 1998.

O Sol do Brasil. Nicolas-Antoine Taunay e as desventuras dos artistas franceses na corte de D. João. São Paulo: Companhia das Letras, 2008.

; com DIAS, Elaine. Nicolas-Antoine Taunay no Brasil: uma leitura dos trópicos. Rio de Janeiro: Sextante, 2008.

SERRERA, Juan Miguel (Org.). Alonso Sánchez Coello y el retrato en la corte de Felipe II: catálogo. Madrid: Museo Nacional del Prado, 1990.

STRONG, Roy. The artists of the Tudor court. The portrait miniature rediscovered. 1520-1620. Londres: Victoria and Albert Museum, 1983.

TAUNAY,Afonso d'Escragnolle. Documentos sobre a vida de Nicolau Antonio Taunay (1755-1830), um dos fundadores da Escola Nacional de Belas Artes. Revista do Instituto Histórico e Geográfico Brasileiro, t. 78, 1915. Rio de Janeiro: Imprensa Nacional, 1916.

.A Missão Artística de 1816. Rio de Janeiro: Patrimônio Histórico e Artístico Nacional, 1957.

THE SERJEANT-PAINTERS. The Burlington Magazine for Connoisseurs, v. 84, n. 493, p. 80-82.Apr. 1944.

VARNER, Eric R. Mutilation and transformation. Damnatio memoriae and roman imperial portraiture. Leiden: Brill, 2004 (Monumenta Graeca et Romana, 10).

VASARI, Giorgio. Vite de' più eccellenti architetti, pittori e scultori.Torino: Einaudi, 2001.

VIDAL, Javier Ortega. La Capilla Sepulcral de Doña Juana en las Descalzas Reales. Una joya en la penumbra. Reales Sítios, Revista del Patrimonio Nacional, v. 35, n. 138, p. 40-54, 1998.

VIVEIROS ARAÚJO, Maria Lucília. Os interiores domésticos após a expansão da economia exportadora paulista. Anais do Museu Paulista, São Paulo, v. 12, p. 129-160, jan.-dez. 2004.

WARNKE, Martin. O artista da corte. Os antecedentes dos artistas modernos. São Paulo: Edusp, 2001. 